\title{
The climate of the Common Era off the Iberian Peninsula
}

\author{
Fátima Abrantes $^{1,2}$, Teresa Rodrigues ${ }^{1,2}$, Marta Rufino ${ }^{2,3}$, Emília Salgueiro ${ }^{1,2}$, Dulce Oliveira ${ }^{1,2,4}$, Sandra Gomes ${ }^{1}$, \\ Paulo Oliveira $^{1}$, Ana Costa ${ }^{5}$, Mário Mil-Homens ${ }^{1}$, Teresa Drago ${ }^{1,6}$, and Filipa Naughton ${ }^{1,2}$ \\ ${ }^{1}$ Portuguese Institute for Sea and Atmosphere (IPMA), Divisão de Geologia Marinha (DivGM), \\ Rua Alferedo Magalhães Ramalho 6, 1495-006 Lisbon, Portugal \\ ${ }^{2}$ CCMAR, Centro de Ciências do Mar, Universidade do Algarve, Campus de Gambelas, 8005-139 Faro, Portugal \\ ${ }^{3}$ IFREMER - Centre Atlantique (French Research Institute for Exploitation of the Sea), \\ Département Ecologie et Modèles pour l'Halieutique (EMH), Rue de l'Ile d'Yeu - \\ BP 21105, 44311 Nantes CEDEX 3, France \\ ${ }^{4}$ Paléoclimatologie et paléoenvironnements marins, Université de Bordeaux, EPOC, UMR 5805, 33615 Pessac, France \\ ${ }^{5}$ Centro de Investigação em Biodiversidade e Recursos Genétics (EnvArchCIBIO/InBIO) and Archaeosciences \\ Laboratory (LARC/DGPC), Rua da Bica do Marquês, 2, 1300-087 Lisbon, Portugal \\ ${ }^{6}$ Instituto Dom Luiz, Universidade de Lisboa, 1749-016 Lisbon, Portugal
}

Correspondence: Fátima Abrantes (fatima.abrantes@ipma.pt)

Received: 12 June 2017 - Discussion started: 27 June 2017

Revised: 17 November 2017 - Accepted: 2 December 2017 - Published: 21 December 2017

\begin{abstract}
The Mediterranean region is a climate hot spot, sensitive not only to global warming but also to water availability. In this work we document major temperature and precipitation changes in the Iberian Peninsula and margin during the last 2000 years and propose an interplay of the North Atlantic internal variability with the three atmospheric circulation modes (ACMs), (North Atlantic Oscillation (NAO), east atlantic (EA) and Scandinavia (SCAND)) to explain the detected climate variability.

We present reconstructions of sea surface temperature (SST derived from alkenones) and on-land precipitation (estimated from higher plant $n$-alkanes and pollen data) in sedimentary sequences recovered along the Iberian Margin between the south of Portugal (Algarve) and the northwest of Spain (Galiza) (36 to $42^{\circ} \mathrm{N}$ ).

A clear long-term cooling trend, from $0 \mathrm{CE}$ to the beginning of the 20th century, emerges in all SST records and is considered to be a reflection of the decrease in the Northern Hemisphere summer insolation that began after the Holocene optimum. Multi-decadal/centennial SST variability follows other records from Spain, Europe and the Northern Hemisphere. Warm SSTs throughout the first 1300 years encompass the Roman period (RP), the Dark Ages (DA) and the Medieval Climate Anomaly (MCA). A cooling initiated at $1300 \mathrm{CE}$ leads to 4 centuries of colder SSTs contemporary
\end{abstract}

with the Little Ice Age (LIA), while a climate warming at $1800 \mathrm{CE}$ marks the beginning of the modern/Industrial Era.

Novel results include two distinct phases in the MCA: an early period (900-1100 years) characterized by intense precipitation/flooding and warm winters but a cooler spring-fall season attributed to the interplay of internal oceanic variability with a positive phase in the three modes of atmospheric circulation (NAO, EA and SCAND). The late MCA is marked by cooler and relatively drier winters and a warmer spring-fall season consistent with a shift to a negative mode of the SCAND.

The Industrial Era reveals a clear difference between the NW Iberia and the Algarve records. While off NW Iberia variability is low, the Algarve shows large-amplitude decadal variability with an inverse relationship between SST and river input. Such conditions suggest a shift in the EA mode, from negative between 1900 and $1970 \mathrm{CE}$ to positive after 1970, while NAO and SCAND remain in a positive phase. The particularly noticeable rise in SST at the Algarve site by the mid-20th century $( \pm 1970)$, provides evidence for a regional response to the ongoing climate warming. The reported findings have implications for decadal-scale predictions of future climate change in the Iberian Peninsula. 


\section{Introduction}

Today's anthropogenically induced global warming poses a pressing problem for societies' sustainability (IPCC, 2013a, b). Regions such as the Arctic and the Mediterranean are highlighted as the most sensitive and potentially vulnerable to ongoing global warming (Climate, 2011; Giorgi, 2006).

Global and regional model simulations for the Iberian Peninsula forecast temperatures rising above the predicted global mean and changes in precipitation consistent with long dry summers and a short and wetter rainy season particularly for the southern region (Guiot and Cramer, 2016; Miranda et al., 2002). Most of this knowledge is based on the analysis of instrumental data and modeling of global and hemispheric average conditions. However, given the limited time span covered by the instrumental data and to better comprehend the impact of climate warming, it is essential to analyze and understand the response of the climate system from the perspective of a longer timescale. In light of the current warming, previous warm periods and warming transitions such as those occurring over the last 2000 years are of particular interest. Proxy-based climate reconstructions and modeling of the climate for the last 1 or 2 millennia in the Northern Hemisphere have identified the late Roman period (RP; 0-500 CE), the Dark Ages (DA; 500-900 CE) and the Medieval Climate Anomaly (MCA; 900-1300 CE), also known as Medieval Warm Period (MWP), and the Little Ice Age (LIA; 1350-1850 CE) and attribute this climate variability mainly to external forcing such as solar and volcanic activity (Fernandez-Donado et al., 2013; Hegerl et al., 2006; Jones et al., 2001; McKim, 1998; Schurer et al., 2014). After $1900 \mathrm{CE}$, the rise in global mean atmospheric temperature is mainly attributed to the unprecedented increase in greenhouse gases in the atmosphere (IPCC, 2013a).

Throughout the last 2 decades, many high-resolution 2000 years climate records have been generated from Iberian lake sediments (e.g., Hernández et al., 2015; JambrinaEnríquez et al., 2016; Morellón et al., 2009; Moreno et al., 2008; Valero-Garcés et al., 2006); speleothems (e.g., MartínChivelet et al., 2011) and marine sediments (e.g., Abrantes et al., 2005; Abrantes et al., 2011; Desprat et al., 2003; Diz et al., 2002; Lebreiro et al., 2006; Pena et al., 2010). These individual evaluations of climate evolution over Iberia, and compiled ones (e.g., Moreno et al., 2011; Sánchez-López et al., 2016), reveal multi-decadal to centennial climate variability in accordance with the main patterns identified for the Northern Hemisphere (Ahmed et al., 2013; Büntgen et al., 2011; Cook et al., 2004; Esper et al., 2002; Luterbacher et al., 2016; Moberg et al., 2005).

Additionally, given the dominance of the North Atlantic Oscillation (NAO) (Hurrell, 1995) in the Northern Hemisphere, most of the above works attribute the variability to changes in the prevailing modes of the NAO (Abrantes et al., 2005, 2011; Lebreiro et al., 2006). In recent years it has been proposed that the east Atlantic (EA) and Scandinavia
(SCAND) modes also play a significant role in North Atlantic climate evolution (Comas-Bru and McDermott, 2014; Hernández et al., 2015; Jerez and Trigo, 2013). SánchezLopez et al. (2016), on the basis of a spatiotemporal integration of several climate reconstructions, attempted to identify the role of those atmospheric patterns over the Iberian Peninsula. Their results reveal E-W and $\mathrm{N}-\mathrm{S}$ humidity gradients from 0 to $500 \mathrm{CE}$ and between 500 and $900 \mathrm{CE}$, respectively, while between 900 and $1850 \mathrm{CE}$ temperature and humidity conditions are more homogenous throughout the peninsula. These conclusions support atmospheric pathways as the main control of climate variability in western Europe on multi-decadal timescales. However, Yamamoto and Palter (2016) observed a clear relationship between the Atlantic Multidecadal Oscillation (AMO) and the atmospheric circulation over Europe, with northerly winds associated with a positive state of the AMO and zonal winds with a negative state of the AMO. To better understand the role of oceanic and atmospheric processes on past climate and their relevance to the Iberian Peninsula's future climate, it is pivotal to obtain more high-resolution climate archives of the most recent centuries and millennia. Here, we explore the main oceanic and atmospheric processes that drive complex spatial climate patterns over the Iberia Peninsula across the last 2000 years by integrating new records from the Iberian Margin, Galiza, Minho and Algarve, with published datasets (Porto and Tagus; Abrantes et al., 2005, 2011; Lebreiro et al., 2006).

\section{Oceanographic conditions}

The western coast of the Iberian Peninsula (Fig. 1) is characterized by contrasting oceanographic conditions between a spring-summer (April to October) coastal upwelling regime and a surface equatorward current (Fiúza, 1982, 1983; Peliz et al., 2002; Relvas et al., 2007) and a winter alongshore poleward warm counter current (Fiúza and Frouin, 1986; Peliz et al., 2005).

The spring-summer upwelling constitutes the northern part of the eastern North Atlantic upwelling/Canary System and is connected to the presence of the Azores high-pressure system and the development of northerly alongshore winds (Fiúza, 1983). Upwelled waters are transported southwards by a jet-like surface current (Fig. 1c), the Portuguese Coastal Current, which is the coastal component of the Portuguese Current that branches of the North Atlantic Current, (Fiúza, 1982, 1983; Fiúza and Macedo, 1982). On the southern coast (Algarve), upwelling favorable conditions are rare, but western upwelled waters flow around Cape S. Vicente and along the south coast, (Fiúza, 1982, 1983; Fiúza and Macedo, 1982; Sánchez and Relvas, 2003) and can spread to its easternmost sector (Cardeira et al., 2013). This eastward flow of cold western upwelled waters alternates with the propagation of westward flows related to warm water and increased vertical 


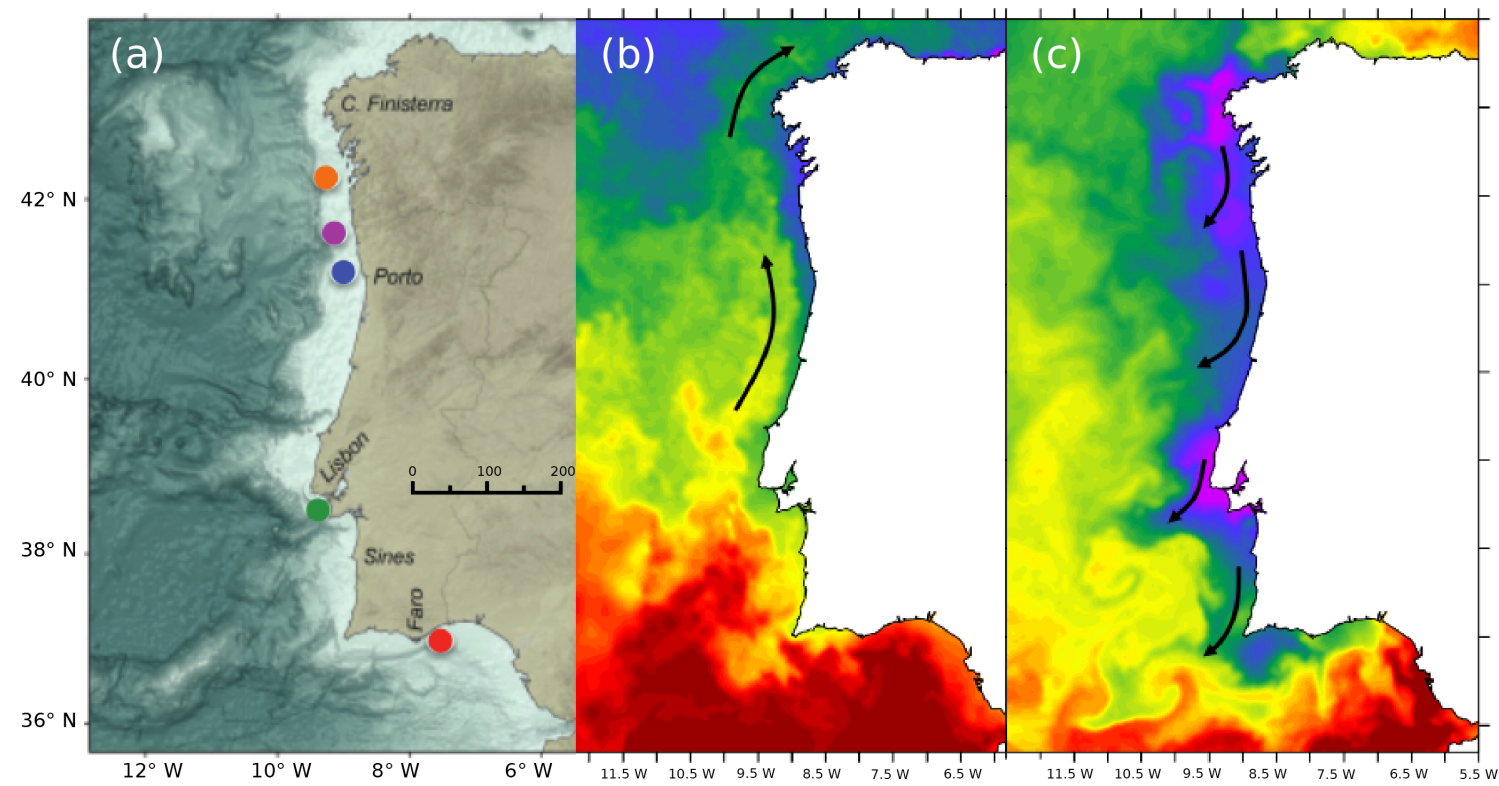

Figure 1. (a): Core locations over Iberian Margin bathymetry: Geoß11033-1/Galiza in orange; DIVA09 GC/Minho in magenta; PO287-6B, -6G/Porto (Douro Mud Belt) in blue; PO287-26B, -26G, D130902, D13882 Tagus (Tagus Mud Belt) in green; POPEI VC2B/Algarve in red. The color assigned to each core location will be applied in all figures. (b): Winter satellite-derived sea surface temperature (SST) image (23 January 2003) showing the surface signature of the Iberian Poleward Current. (c): Summer SST image illustrating coastal upwelling conditions (colder coastal SST) along the western Iberian Margin (3 August 2005). Panels (b) and (c): land covered areas appear in white; the color shades were selected to highlight the main oceanographic structures; the image source is JPL-PODAAC (https://mur.jpl.nasa.gov/)

stratification showing a direct relationship between flow velocity and water temperature (Garel et al., 2016; Relvas and Barton, 2002).

In winter, the prevalence of westerly or southwesterly winds leads to the intensification of the Iberian Poleward Current (Fig. 1b). This current, which is a branch of the Azores Current, consists of an upper-slope-shelf-break poleward flow that transports saltier and warmer (subtropical) waters (Peliz et al., 2005) depending mostly on the intensity of the southerly winds (Teles-Machado et al., 2015). Another important feature of the winter circulation over the western margin is the formation of coastal buoyant plumes, characterized by low salinities and temperature lower than the ambient shelf waters (Peliz et al., 2005). Such plumes result from the freshwater discharge from rivers, thus reflecting continental precipitation. Precipitation occurs mainly in winter, as a result of the moisture carried onto the peninsula by the westerly winds, and has important latitudinal differences, from $500 \mathrm{~mm} \mathrm{yr}^{-1}$ in the southeast to $>3000 \mathrm{~mm} \mathrm{yr}^{-1}$ in the northwestern area (Miranda et al., 2002). As a consequence, buoyant plumes are mainly associated with the major northern Portuguese rivers (Minho, Douro, Mondego) but are also linked to the Tagus River and can either develop into inshore currents (under typical winter downwelling conditions) or spread offshore under northerly wind conditions (Iglesias et al., 2014; Marta-Almeida et al., 2002; Mendes et al., 2016; Oliveira et al., 2007; Otero et al., 2008).

\section{Material and methods}

This study combines proxy data previously published for sedimentary sequences collected off the Tagus River (PO287-26B and -26G, D13902 and D13882 designated as Tagus; Abrantes et al., 2005; Rodrigues et al., 2009) and Douro River (PO287-6B and -6G, designated as Porto; Abrantes et al., 2011) with new data from three other sites on the Iberian Margin (Table 1, Fig. 1). Two of the new sites are located in the northern area, off Vigo (GeoB11033-1 referred to as Galiza) and off the Minho River mouth (DIVA09 GC, referred to as Minho in this paper), and one core is from the southern Iberian/Algarve margin (POPEI VC2B, referred to as Algarve). With the exception of the Galiza deep-sea core, all other sedimentary sequences were collected on the inner shelf in areas directly affected by river discharge.

Age models of the three new cores (Galiza, Minho and Algarve), were constructed using the methods of Abrantes et al. $(2005,2011)$ and are based on accelerator mass spectrometry radiocarbon $\left(\mathrm{AMS}{ }^{14} \mathrm{C}\right)$ and ${ }^{210} \mathrm{~Pb}$-inferred dates (Sect. 1, Table S1, Figs. S1 and S2 in the Supplement). Raw AMS ${ }^{14} \mathrm{C}$ dates were corrected for marine reservoir ages of 400 years \pm 36 (Abrantes et al., 2005) and converted to calendar ages using INTCAL04 (Reimer et al., 2004). The obtained calendar ages correspond to years Anno Domini, now designated by Common Era (CE; McKim, 1998).

Sea surface temperature (SST) was determined based on the ratio of alkenones $\left(\mathrm{U}_{37}^{k^{\prime}}\right)$ synthesized by coccolithophores 
Table 1. ID, water depth, geographic location, core type, sampling cruise, sedimentation rate (SR) and age-model origin of the seven sedimentary sequences used in this study.

\begin{tabular}{llrllllll}
\hline Site & ID & $\begin{array}{r}\text { Water } \\
\text { depth } \\
(\mathrm{m})\end{array}$ & Lat N & Long W & Core type & Cruise & SR & Age model \\
& & & & & & \\
$\left(\mathrm{mm} \mathrm{yr}^{-1}\right)$
\end{tabular}

(phytoplankton group) (e.g., Eglinton et al., 1992; RosellMelé et al., 1994; Villanueva and Grimalt, 1997). Lipid compounds synthesized by higher plants, such as C23-C33 $n$-alkanes ([n-alk]) (e.g., Eglinton and Hamilton, 1967), and the total pollen concentration (TPC) were used as indicators of river discharge intensity and on-land precipitation regime (e.g., Rodrigues et al., 2009). Major changes in vegetation cover, that is, continental temperature and moisture conditions, were evaluated from pollen assemblages (Naughton et al., 2007).

Alkenones and higher plant $n$-alkanes were analyzed on $2 \mathrm{~g}$ of homogenized sediment using a Varian gas chromatograph Model 3800 equipped with a septum programmable injector and a flame ionization detector at the DivGMIPMA (Divisão de Geologia Marinha - Instituto do Mar e da Atmosfera) laboratory according to the methods described in Villanueva (1996) and Villanueva et al. (1997). The analytical error was $0.5^{\circ} \mathrm{C}$. The concentration of each compound was determined using hexatriacontane as an internal standard. For the calculation of SST, we selected the globally defined calibration of Muller et al. (1998) $\left(\mathrm{U}_{37}^{k^{\prime}}=0.033 \times \mathrm{SST}-0.044\right)$. Both alkenone-based SST and [n-alk] are widely accepted proxies for SST and river input, but to better understand our regional records, the significance of our high-resolution sediment data was assessed by comparison to NOAA daily Optimum Interpolation Sea Surface Temperature (OISST, V2 AVHRR-only) dataset (Fig. S3) and the river discharge dataset at Sistema Nacional de Informação de Recursos Hídricos (SNIRH).

Sample preparation procedures for pollen analyses followed the methods described in Naughton et al. (2007). Pollen and spores were counted using a Nikon light microscope at $\times 550$ and $\times 1250$ (oil immersion) magnification. Pollen identification was done via comparison with the pollen atlases of Moore et al. (1991) and Reille (1992). A minimum of 100 Lycopodium grains, 20 pollen types and 100 pollen grains, excluding the overrepresented Pinus, have been counted (Naughton et al., 2007). Pollen was gathered in two main groups: AP (arboreal pollen) including all trees and shrubs but excluding the overrepresented pine taxa; the semi- desert plants, which groups xerophytic shrubs of semi-desert habitats (Artemisia, Chenopodiaceae, Ephedra).

To reduce the local variability signal and better evaluate the multi-decadal record at the regional level, a stack of all the cores was generated from the SST and $n$-alkanes original records on their original age models. Each record was standardized (subtracting each value by the mean) and scaled (dividing the centered columns by their standard deviation). This technique weights high-resolution records more heavily and prevents interpolation across gaps or hiatuses from affecting the stack (Lisiecki and Raymo, 2005). Additionally, a test of the sensitivity of the stack to the bin size and the inadequacies of the proxy data (Supplementary Material) reveals that the stack is insensitive to bin sizes (20-50 years) and independent of data deficiencies (Fig. S4). To focus on lower-variability periods, a similar stack was built using a 5year bin size and the Porto, Tagus and Algarve cores with a sedimentation rate $>0.4 \mathrm{~cm} \mathrm{yr}^{-1}$ (Fig. S3, bottom panel).

To investigate the existence of periodic signals and potential changes in their amplitude through time, we carried out a continuous time series transformation with a Morlet wavelet analysis on each dataset and stack (Torrence and Compo, 1998) after interpolation of the series to regular time steps. Interpolation was done using a cubic-splines method, and the temporal resolution of the interpolation was established as half of the absolute median difference between every consecutive time interval. Data were then detrended using a modified negative exponential curve, as required for the analysis. All statistical analysis was done using the libraries bi-wavelet (Akima and Gebhardt, 2016; Gouhier et al., 2016), from R project (R Core Team, 2016).

\section{Results}

All the sedimentary sequences selected for this study have exceptionally high sedimentation rates in the upper levels, allowing for a very high temporal resolution of 2-3 years in the top sediments. In the older part of the sequences, larger sampling intervals and/or lower sedimentation rates provide a temporal resolution of \pm 30 years. Additionally, the analyses of SST and multiple proxies for on-land precipitation 


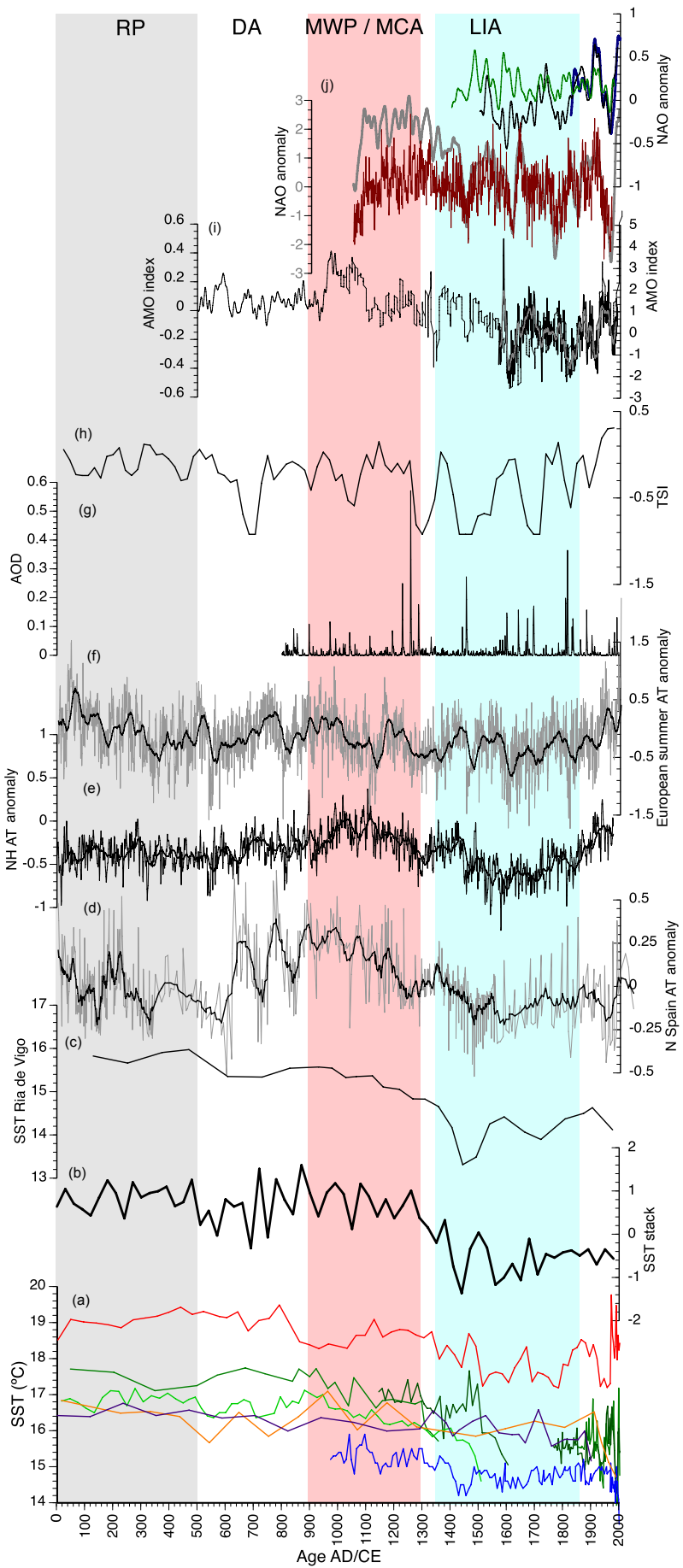

Figure 2. Comparison of $\mathrm{U}_{37^{\prime}}$-SST over the last 2000 years at sites Galiza (orange), Minho (magenta), Porto (blue), Tagus (green) and Algarve (red) (a); SST stack constructed from all Iberian Margin records (b); $\mathrm{U}_{37}^{k^{\prime}}$-SST at Ria de Vigo (Diz et al., 2003) (c); Northern Hemisphere annual mean atmospheric temperature anomaly (Moberg et al., 2005) (d); northern Spain atmospheric temperature anomaly (Martín-Chivelet et al., 2011) (e); European spring-fall atmospheric temperature anomaly (Luterbacher et al., 2016) (f); volcanic activity as aerosol optical depth (AOD) (Crowley and Unterman, 2013) (g); radionuclide-derived total solar irradiance (TSI) (Bard et al., 2007) (h); Northern Atlantic Ocean SST anomaly and AMO index (gray - Mann et al., 2010; black - Gray et al., 2004) (i); NAO index (Luterbacher et al., 2002; brown, Trouet et al., 2009) (j). Light gray band marks the RP; the pink band marks the MCA; the blue band marks the LIA. 
from the same sediments allows us to accurately evaluate the coupled ocean and land variability without chronological ambiguity. Furthermore, to better assess the regional value of $\mathrm{U}_{37}^{k^{\prime}}$-SST and [ $n$-alk], sediment-derived variables were compared to climatological datasets (Sects. S2 and S3 in the Supplement). Results validate the proxies and reveal that in the west coast, SST compares to winter climatological data but in the Algarve, SST mimics spring-fall (Fig. S2), providing the opportunity to disentangle winter from spring-fall conditions in the region.

\subsection{Sea surface temperature}

SSTs are minimal off Porto $\left(14\right.$ to $\left.16^{\circ} \mathrm{C}\right)$ and maximal in the Algarve $\left(17\right.$ to $20^{\circ} \mathrm{C}$ ), while average temperatures are observed in the Tagus, Minho and Galiza $\left(15\right.$ to $\left.18^{\circ} \mathrm{C}\right)$ as shown in Fig. 2a by the alkenone-derived SST reconstructions for all seven Iberian Margin records. The temperature difference between the areas is maintained throughout the last 2000 years, but the amplitude of decadal-secular variability is higher at the Tagus and Algarve sites $\left(3^{\circ} \mathrm{C}\right)$ than the $1.5^{\circ} \mathrm{C}$ detected in the northern sites (Porto, Minho and Galiza) (Fig. 2a). Moreover, the SST stack (Fig. 2b) reveals an overall long-term cooling trend from $0 \mathrm{CE}$ to the beginning of the 20th century, with a stronger gradient at the Tagus $\left(2.5^{\circ} \mathrm{C} / 2000\right.$ years $)$ than at the other sites $\left(1^{\circ} \mathrm{C} / 2000\right.$ years) (Fig. 2a). This longterm cooling follows the gradual decrease in Northern Hemisphere summer insolation across the Holocene reported for this region by Rodrigues et al. (2009) but also observed in other European and worldwide records (Ahmed et al., 2013; Luterbacher et al., 2016; McGregor et al., 2015).

Superimposed on the long-term cooling, both the individual SST records (Fig. 2a) and the SST stack (Fig. 2b) display century-scale variability comparable with that recorded in both the oceanic and continental environments of northern Spain (Fig. 2c, d) as well as in other European and Northern Hemisphere records (Fig. 2e, f) (Diz et al., 2002; Luterbacher et al., 2016; Martín-Chivelet et al., 2011; Moberg et al., 2005). Relatively high SSTs occur during the first nine centuries encompassing the late RP and the DA (Fig. 2a, b), mainly at the southern sites (Tagus and Algarve; Table 2). Consistently warmth conditions are also recognized at all sites between 900 and $1300 \mathrm{CE}$ within the MCA (Fig. 2a, b). The western Iberia records reveal a warmer first phase in the MCA in agreement with data for the NE North Atlantic (Cunningham et al., 2013). However, at the Algarve site SST decreases during the MCA, between 800 and $1100 \mathrm{CE}$, followed by an increase of $\pm 1{ }^{\circ} \mathrm{C}$ between 1100 and $1300 \mathrm{CE}$.

A transition from warm to cold climatic conditions starts around 1300 CE (Fig. 2b) associated with the Wolf solar minimum (Fig. 2h) (Bard et al., 2007). Cold conditions prevail for most of the 15th to 18th centuries in western Iberia, during the well-known LIA (Bradley and Jones, 1993). SSTs are colder than during the MCA by an average $0.5^{\circ} \mathrm{C}$ at the northern sites and $1.2^{\circ} \mathrm{C}$ at the southern sites, particularly in the high-resolution LIA record from the Algarve (Fig. 2a). Abrupt cold episodes are synchronous with solar minima and major volcanic events (Fig. 2g, h) (e.g., Crowley and Unterman, 2013; Solanki et al., 2004; Steinhilber et al., 2012; Turner et al., 2016; Usoskin et al., 2011).

At $1800 \mathrm{CE}$ an increase in SST marks the transition to warm modern times referred to as the Industrial Era. During the 20th century, unusually large decadal-scale SST oscillations are recorded at the southern sites, in particular in the Algarve, where a more abrupt rise in SST occurs by the mid20th century at around 1970 CE (Fig. 2a), coinciding with the Great Solar Maximum (1940-2000) (Usoskin et al., 2011).

Such an increase in the amplitude of SST variation during the last 50 years, in particular at the Algarve site, although attributable to better proxy preservation in the more recent sediments (Calvert and Pedersen, 2007), is certainly also a reflection of the regional reaction to an intensification of climatic extremes, an expected response to the ongoing climate warming (IPCC, 2013a; Miranda et al., 2002).

\subsection{Continental precipitation}

At present there is a clear north-south difference in the precipitation regime, with higher mean annual precipitation in the north versus the southern region (Miranda et al., 2002). In our records, the lowest lipid compounds synthesized by continental plants $\left(\left[n\right.\right.$-alk]) $\left(100-700 \mathrm{ng} \mathrm{g}^{-1}\right)$ are found at Galiza, the deepest $(1873 \mathrm{~m})$ and more oceanic site, while the highest $\left[n\right.$-alk] (1000 to $7000 \mathrm{ng} \mathrm{g}^{-1}$ ) mainly reflect the large Douro River discharge. The Minho, Tagus and Algarve sites that are influenced by the intermediate mean annual discharge rivers Minho, Tagus and Guadiana (Miranda et al., 2002), show intermediate $\left[n\right.$-alk] (700-4000 $\left.\mathrm{ng} \mathrm{g}^{-1}\right)$ (Fig. 3a).

The total [ $n$-alk] stack (Fig. 3b) highlights abrupt decadalscale variability in river discharge throughout the first 900 years, with relatively lower mean values during the DA (Fig.3b). In the MCA, a strong positive deviation occurs in the early MCA (980-1100 CE), mainly reflecting the extreme river discharge in Porto, since reduced river discharge is recorded at the Tagus and Algarve sites (Fig. 3a). From 1100 to $1200 \mathrm{CE}$, river discharge is still low in the southern cores, and Porto reaches minimum values. After 1200 CE, throughout the late MCA to the beginning of the LIA, a gradual increase in the total [ $n$-alk] reflects a persistent river flow at all latitudes (Fig. 3a, b). As found for SST, river input during the Industrial Era shows large-amplitude variability in the southern cores and the Algarve in particular.

Iberian precipitation variability reflects changes in river discharge intensity, which can also be estimated from oscillations in TPC (Naughton et al., 2009). TPC data, although at a very low temporal resolution, are available for three locations: Minho, Tagus and the Algarve (Fig. 3c). The TPC data suggest a much larger river discharge during the RP at the Tagus (core D13882) than in the Minho or the Al- 
Table 2. Mean U $k_{37}^{\prime}$ SST at the Iberian Margin during the major climatic periods of the last 2000 years. The italic and bold font highlight, respectively, colder and warmer periods.

\begin{tabular}{llrrrrr}
\hline & & \multicolumn{5}{c}{ Mean SST } \\
\cline { 3 - 7 } & Common Era & Galiza & Minho & Douro & Tagus & Algarve \\
\hline $\begin{array}{llrrrr}\text { Roman-Dark Ages } \\
\text { Medieval Warm }\end{array}$ & $<900$ & 16.0 & $\mathbf{1 6 . 5}$ & - & $\mathbf{1 7 . 5}$ & $\mathbf{1 9 . 1}$ \\
$\begin{array}{l}\text { Period } \\
\text { Little Ice Age }\end{array}$ & $900-1300$ & $\mathbf{1 6 . 6}$ & 16.2 & $\mathbf{1 5 . 3}$ & 17.1 & 18.7 \\
Modern times & $1350-1850$ & 16.1 & 15.9 & 14.7 & $15.6^{*}$ & 17.8 \\
& $>1900$ & 15.5 & - & 14.7 & 15.5 & 18.3 \\
\hline
\end{tabular}

* Existing sediment hiatus likely affected estimated value.

garve. During the DA and the MCA, TPC-derived riverine input/precipitation is higher in the Minho and Tagus hydrological basins than in the Algarve, but at $1400 \mathrm{CE}$ the Algarve record rises to higher values, comparable to those observed at the Minho, in accordance with $[n$-alk] (Fig. 3a, c).

To substantiate our $[n$-alk] and TPC records of on-land precipitation, we compared our data to various reconstructions and historical documents of Iberian flood events. For the Tagus, flood reconstructions were based on the hydrological basin terraces (Benito et al., 2005, 2004, 2003) and the Taravilla Lake sediment record from the headwaters of the Tagus River (Moreno et al., 2008). Historical documentation was provided by Tullot (1988) for the Douro and Minho rivers and by Barriendos and Rodrigo (2006) for most Iberian Peninsula basins including the coastal Mediterranean, and there were daily journals for the most recent flood events of the Guadiana River (Barriendos and Martin-Vide, 1998; Barriendos and Rodrigo, 2006; Cabrita, 2007; Varzeano, 1976) (Table 3; Fig. 3). Despite age uncertainties, the stack [ $n$-alk] maxima between 980 and $1100 \mathrm{CE}$ coincide with reports of major flooding events in both the Douro and Minho rivers (Tullot, 1988). Other periods marked by strong precipitation occur in the MCA between 1180 and 1200 CE and again at the beginning of the LIA, from 1450 to $1470 \mathrm{CE}$ (Tullot, 1988). At the Tagus site, the [ $n$-alk] record also agrees with significant river flooding phases (1200-1300 CE; 19501980 CE) (Benito et al., 2003, 2004; Benito and Hudson, 2010). The Algarve site, located $80 \mathrm{~km}$ to the west of the Guadiana River mouth, appears to record not only the most recent flooding events (1876 and $1979 \mathrm{CE}$ ) reported in newspapers (Cabrita, 2007; Varzeano, 1976) but also the Atlantic Basin flooding events (Barriendos and Rodrigo, 2006; Benito et al., 2004). The similarity of the independently identified records of storm or flooding periods for the various regions leads to the conclusion that the maxima in $[n$-alk] can indeed be attributed to extreme precipitation and flooding conditions (Fig. 3).

\subsection{Atmospheric temperature}

Arboreal (AP) and semi-desert pollen variability at the Minho, Tagus and Algarve sites were compared with the same pollen curves from the Ria de Vigo (Desprat et al., 2003) and were found to reflect the main forest and climate changes over the last 2000 years (Fig. 4a, b). Major forest expansion, revealed by increasing AP percentages, occurs during the RP and the MCA, indicating relatively warm conditions on-land (Fig. 4b). In contrast, a reduction of the forest cover, revealed by the decrease in arboreal pollen, suggests relatively cold conditions during the LIA (Fig. 4b). Between $1700-1800 \mathrm{CE}$ there is a strong decrease in arboreal pollen in the Algarve and Minho, suggesting an abrupt cooling episode over Iberia (Fig. 4b). After $1800 \mathrm{CE}$ a new increase in AP reflects climate warming over the continent. AP variability in western Iberia over the last 2000 years shows no clear match with European summer atmospheric temperature or spring precipitation (Fig. 4f, g) but agrees with the general trend of northern Spain's stalagmite T anomaly (Fig. 4e) (MartínChivelet et al., 2011) and AP variability at the Ria de Vigo (Fig. 4b) (Desprat et al., 2003).

Semi-desert plant values are highest in the Algarve (although with a modest $8 \%$ contribution), lower at the Tagus site and further reduced at the Minho site, showing clearly the north to south precipitation contrast (Fig. 4a). Between 1700 and $1800 \mathrm{CE}$ (within the LIA), a marked decrease in both arboreal taxa and semi-desert plants is observed and co-occurs with abrupt shifts between periods of an increased frequency of strong rain events (Barriendos and Martin-Vide, 1998) and periods of prolonged drought (Barriendos, 2002; Benito and Hudson, 2010). Furthermore, this interval also coincides with a period of stable temperature in northern Spain and minima in European seasonality and spring atmospheric temperature in Europe (Fig. 4e, h, i) (Luterbacher et al., 2004) as well as a minimum in spring-summer and winter precipitation (Fig. 4c, j, k) (Martín-Chivelet et al., 2011; Romero-Viana et al., 2011; Touchan et al., 2005). 


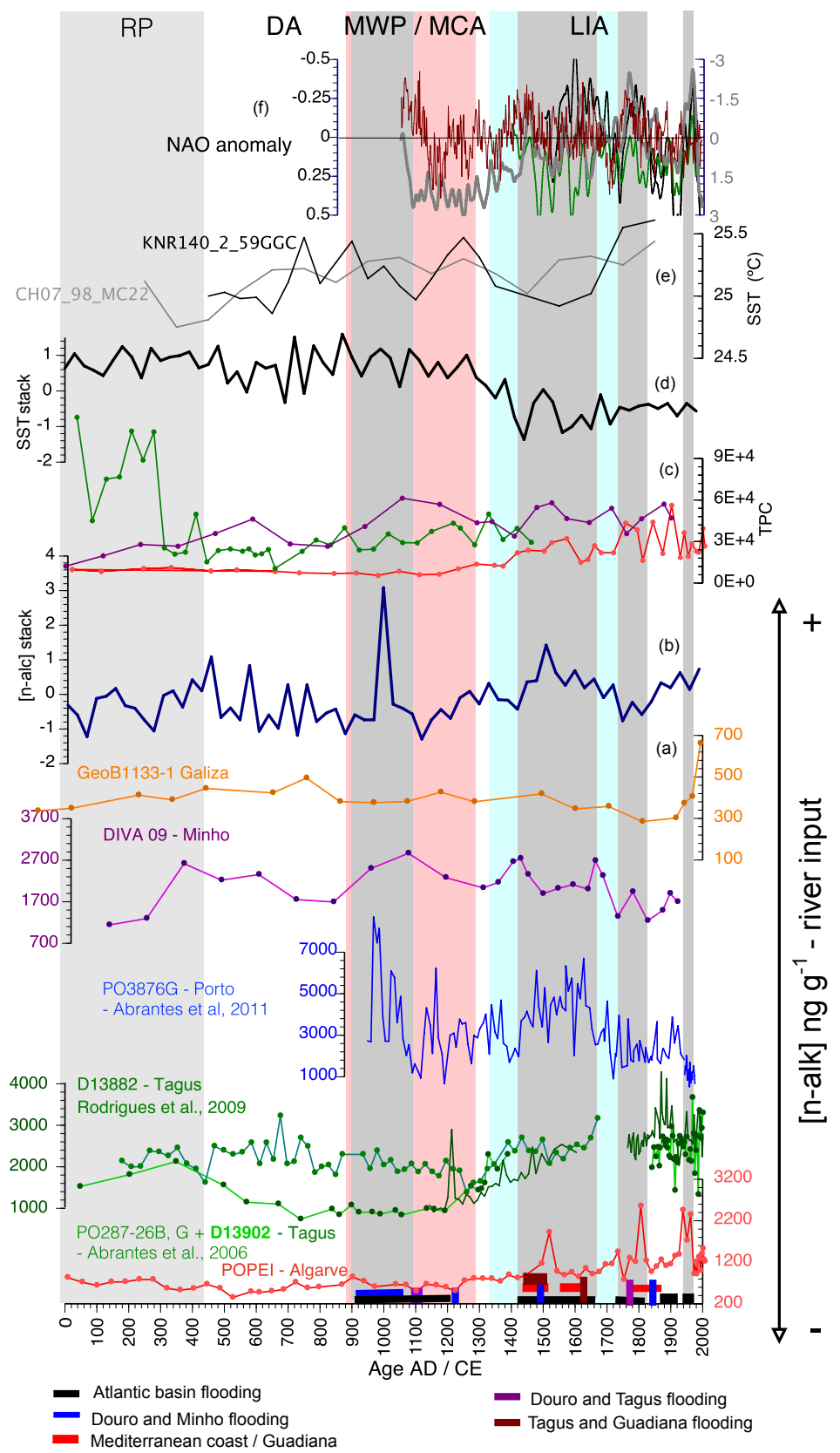

Figure 3. (a): $\left[n\right.$-alk] $\left(\mathrm{ng} \mathrm{g}^{-1}\right)$ variability over the last 2 millennia and the five Iberian Margin sites; colors are as in Fig. 3. (b): The [n-alk] stack anomaly. (c): Total pollen concentration (TPC, no pollen grains $\mathrm{cm}^{-3}$ sediment). (d): SST stack anomaly. (e): SST NW Atlantic cores KNR140-2-59GGC and CH07-98-MC22 (Saenger et al., 2011). (f): NAO index (black line - Luterbacher et al., 2002; green line - Cook et al., 2002; gray line - Trouet et al., 2009; brown line - Ortega et al., 2015). Dark gray bands mark the periods of Atlantic flooding as listed in Table 3. Light gray band marks the RP; the pink band marks the MCA; the blue band marks the LIA.

\section{Discussion}

\subsection{Climate forcing mechanisms}

Climate reconstructions for the Iberian Peninsula are complex because the seasonal variation in the oceanographic system along the Iberian Peninsula margin generates mul- tiple conditions, the combination of which is likely to vary through time. Nevertheless, the use of multiple proxies for each core and at several sites, together with the regional anomaly stack, allows for more robust climatic configurations to be identified. Furthermore, our assessment of the regional SST records (Fig. S2) indicates that SSTs are compa- 


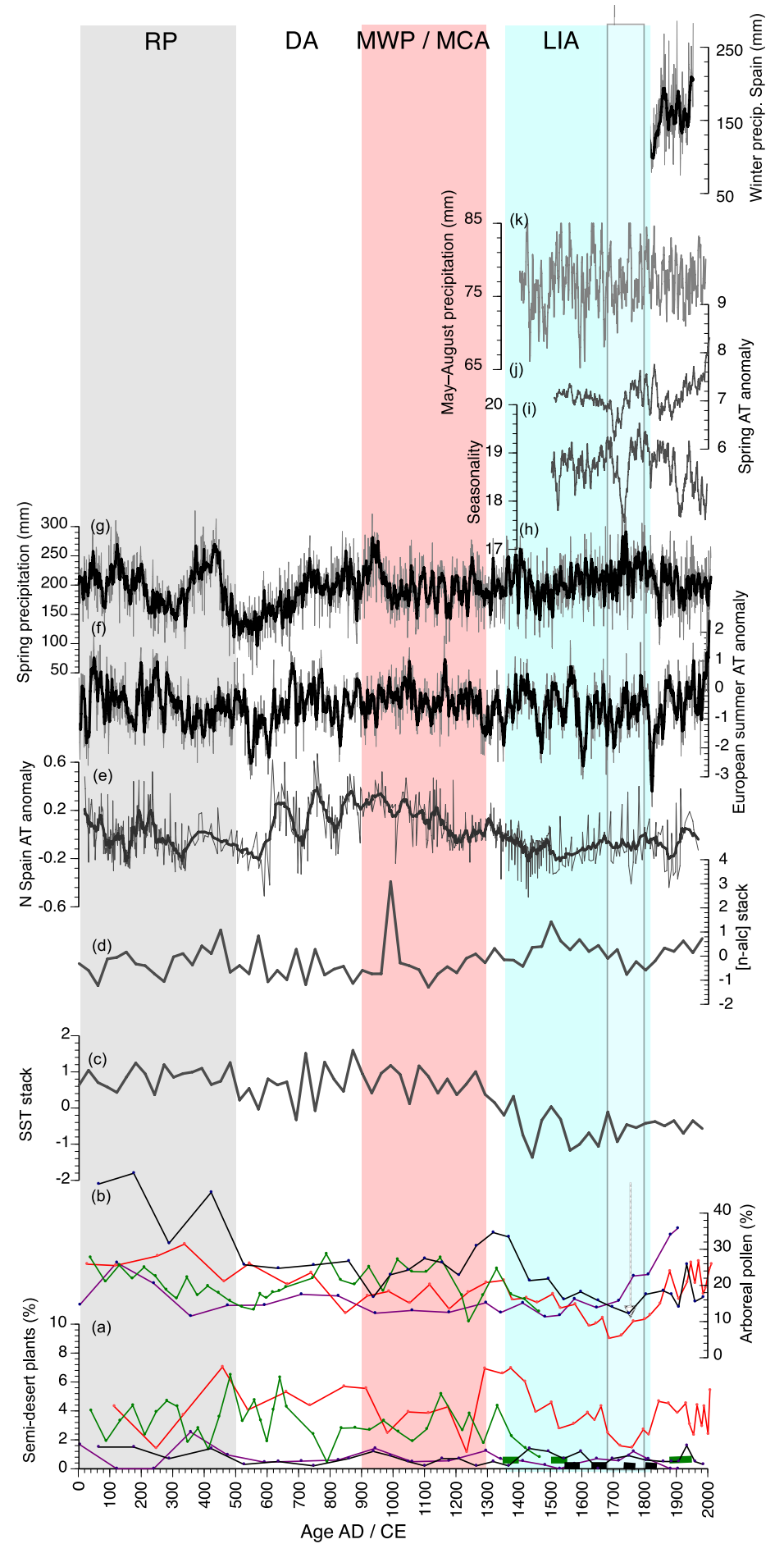

Figure 4. Variability in semi-desert plant percentages over the 2000 years in cores DIVA, Tagus, POPEI and Ria de Vigo (magenta, green, red and black, respectively) (Desprat et al., 2003) (a); arboreal pollen percent abundance (b); the SST stack (c); the [ $n$-alk] stack (d); northern Spain atmospheric temperature anomaly (Martín-Chivelet et al., 2011) (e); European spring-fall atmospheric temperature anomaly (Luterbacher et al., 2016) (f); spring precipitation central Europe (Büntgen et al., 2011) (g); European seasonality (h); spring AT (Luterbacher et al., 2004) (i); May-August precipitation (Touchan et al., 2005) (j); winter (DJFM) precipitation (Romero-Viana et al., 2011) (k). Light gray band marks the RP; the pink band marks the MCA; the blue band marks the LIA. 
Table 3. Compilation of flooding and drought events on the western Iberian Peninsula, according to published information for the MCA, the LIA and the modern/Industrial Era. The italic font refers to the documentary sources.

\begin{tabular}{|c|c|c|c|c|c|c|}
\hline \multicolumn{7}{|c|}{ Floods } \\
\hline Period/region & Atlantic Basin & Douro \& Minho & Tagus & Guadiana & References & Observations \\
\hline MCA & $\begin{array}{l}1000-1200^{*} \\
1150-1290\end{array}$ & $\begin{array}{l}1000-1100 \\
1180-1200\end{array}$ & $\begin{array}{l}785-1205^{*} \\
1150-1200\end{array}$ & & $\begin{array}{l}\text { Benito et al. (2003) } \\
\text { Tullot (1988) } \\
\text { Benito et al. (2003) } \\
\text { Benito et al. (2010) } \\
\text { Benito et al. (2003) } \\
\text { Tullot (1989) }\end{array}$ & $\begin{array}{l}\text { Increased magnitude and frequency } \\
\text { Doc. sources } \\
\text { Sediment records } \\
\text { Max from doc. sources } \\
\text { Sediment records } \\
\text { Doc. sources }\end{array}$ \\
\hline LIA & $\begin{array}{l}1590-1610 \\
1730-1810^{*} \\
1730-1760 \\
1780-1810\end{array}$ & $\begin{array}{l}1434-L C F \\
1450-1470 \\
1545-L C F \\
1626-V L C F^{*} \\
1636-L C F \\
1778-L E F\end{array}$ & $\begin{array}{l}1450-1500 \\
1626-V L E F^{*} \\
1637-L C E\end{array}$ & $\begin{array}{l}1434-L C E \\
1450-1500 \\
1545-L C E \\
1570-1630 \\
1626-V L C F^{*}\end{array}$ & $\begin{array}{l}\text { Benito et al. (2010) } \\
\text { Barriendos and Rodrigo (2010) } \\
\text { Tullot (1988) } \\
\text { Benito et al. (2003) } \\
\text { Barriendos and Rodrigo (2010) } \\
\text { Barriendos and Martín-Vide (1998) } \\
\text { Benito et al. (2004) } \\
\text { Barriendos and Rodrigo (2010) } \\
\text { Barriendos and Rodrigo (2010) } \\
\text { Benito et al. (2010) } \\
\text { Benito et al. (2003, 2004) } \\
\text { Barriendos and Martín-Vide (1998) } \\
\text { Barriendos and Rodrigo (2010) } \\
\text { Benito et al. (2004) }\end{array}$ & $\begin{array}{l}\text { Sediment records \& doc. sources } \\
\text { Doc. sources } \\
\text { Doc. sources } \\
\text { High-frequency lower magnitude } \\
\text { Doc. sources } \\
\text { Mediterranean area - doc. sources } \\
\text { Doc. sources } \\
\text { Doc. sources } \\
\text { Doc. sources } \\
\text { Doc. sources } \\
\text { Sediment records \& doc. sources } \\
\text { Mediterranean area - doc. sources } \\
\text { Doc. sources } \\
\text { Doc. sources }\end{array}$ \\
\hline Modern & $\begin{array}{l}1870-1900 \\
1930-1950 \\
1960-1980\end{array}$ & $\begin{array}{l}1853-L E F \\
1860-L C F\end{array}$ & $\begin{array}{l}1860-L C F \\
\\
1670-1950^{*} \\
1950-1980\end{array}$ & $\begin{array}{l}1876 \\
1979\end{array}$ & $\begin{array}{l}\text { Barriendos and Rodrigo (2010) } \\
\text { Barriendos and Rodrigo (2010) } \\
\text { Benito et al. (2003) } \\
\text { Benito et al. (2003) } \\
\text { Benito et al. (2003) } \\
\text { Benito et al. (2003) } \\
\text { Benito et al. (2004) }\end{array}$ & $\begin{array}{l}\text { Doc. sources } \\
\text { Doc. sources } \\
\text { Sediment records } \\
\text { Sediment records } \\
\text { Sediment records } \\
\text { High-frequency lower magnitude } \\
\text { Doc. sources }\end{array}$ \\
\hline & & & & Droughts & & \\
\hline MWP & & & & $1361-1390$ & Barriendos and Martín-Vide (1998) & \\
\hline LIA & $\begin{array}{l}1540-1570 \\
1625-1640 \\
1750-1760 \\
1810-1830\end{array}$ & & & $1880-1950$ & $\begin{array}{l}\text { Barriendos and Martín-Vide (1998) } \\
\text { Barriendos (2002) } \\
\text { Barriendos (2002) } \\
\text { Barriendos (2002) } \\
\text { Barriendos (2002) } \\
\text { Barriendos and Martín-Vide (1998) }\end{array}$ & $\begin{array}{l}\text { Severe } \\
\text { Severe } \\
\text { Less severe } \\
\text { Less severe }\end{array}$ \\
\hline Modern & $1880-1910$ & & & & Barriendos (2002) & Less severe \\
\hline
\end{tabular}

LCF - large catastrophic flood; LEF - large extraordinary flood; VLCF - very large catastrophic flood; VLEF - very large extraordinary event; LCE - large catastrophic event. * Catastrophic event.

rable with winter temperatures on the west coast, while in the Algarve SST match spring-fall temperatures (Fig. S2), giving us the opportunity to disentangle winter from spring-fall conditions in the region.

The Iberian Peninsula margin was relatively warm from 0 to $1300 \mathrm{CE}$, in particular during the final stage of the RP and the MCA (900-1300 CE), while SST slightly decreases during the DA (Fig. 2b). The LIA, which is clearly colder, lasts from 1350 to $1850 \mathrm{CE}$, when a rise in SST marks the transition to modern times/Industrial Era. This initial augmentation in SST is followed by a second more abrupt mid20th-century SST rise, particularly evident at the southernmost site (Fig. 2a).

In terms of on-land precipitation, the early MCA is a period of extreme precipitation and flooding, mainly from the Douro River (Porto site) (Fig. 3a, b). During the LIA, fre- quent but less extreme precipitation is inferred at all sites, with apparent periods of flooding that are in agreement with other flooding records (e.g., Barriendos and Martin-Vide, 1998; Benito et al., 2005; Cabrita, 2007; Moreno et al., 2008; Tullot, 1988; Varzeano, 1976). Southern Iberian Margin records also show evidence of the well-known major storm events of the 20th century.

The dominant large-scale climate mode operating in the Northern Hemisphere is the NAO (Hurrell, 1995). Being mainly a winter season mode that varies on scales of days to decades, it translates into strong northerly winds and conditions favorable to coastal upwelling during positive phases, while during NAO-negative phases (also known as "blocked"), westerly/southwesterly winds predominate and result in very cold winters and increased storm activity (Hurrell, 1995; Trigo et al., 2004). 
Other prominent atmospheric circulation modes, the EA and the SCAND (Comas-Bru and McDermott, 2014; Jerez and Trigo, 2013), constitute second leading modes that interplay with the NAO. Their temporal variability must also have played a role in climatic evolution in the Northern Hemisphere. The EA has a strong influence on the strength and location of the NAO dipoles mainly on multi-decadal timescales and exerts a major control on winter and summer temperature over the Iberian Peninsula (Hernández et al., 2015). The SCAND functions as a blocking high-pressure system that changes the westerly wind path and influences southwestern Europe mainly during its positive phase, when it contributes to below-average temperatures and aboveaverage precipitation (Hernández et al., 2015). The regional effect of all three atmospheric circulation modes (ACMs) on SST and precipitation over the Iberian Peninsula, for winter and summer periods, is presented in Fig. 5 of Hernández et al. (2015). With regard to the Atlantic coast, besides the negative relationship observed between NAO and winter precipitation, the EA and SCAND are also positively related to winter precipitation, particularly on the northern Iberian Peninsula. In summer, there is a slight positive relationship between SCAND and precipitation in the north but an important negative effect with temperature in most of the south.

The compilation of Sánchez-Lopes et al. (2015) concludes that the climate of the Iberian Peninsula during the last 2000 years has been modulated by the combined effect of two main modes of atmospheric circulation: the NAO and the EA. Negative NAO and positive EA generate warm atmospheric temperatures and higher humidity in the west and south of the Iberian Peninsula during the RP. positive NAO and negative EA cause a more humid north with a W-E humidity gradient during the DA. Consistently warm and dry conditions during the MCA throughout the Iberian Peninsula are attributed to NAO-positive and EA-positive modes. By contrast, NAO and EA negative modes are considered to explain the cold and wet winters, as well as, the cold summers proposed for the LIA.

Although our results might be explained by the abovedescribed mechanisms proposed by Sánchez-Lopez for the RP, the DA and the LIA (Figs. 2, 3, 4), the climate conditions detected in the MCA and the Industrial Era need further discussion.

\subsection{The particular case of the MCA and the Industrial Era}

\subsubsection{The MCA: precipitation distribution and the storm track}

Dry and warm winters as well as warm summers are likely to be generated by the prevalence of NAO- and EA-positive modes as proposed by Sánchez-Lopes et al. (2015). Stronger coastal upwelling conditions have also been suggested to explain the productivity record of the Tagus site. This would imply prevailing northerly winds and an active Portuguese Current, which would equate to a positive NAO-like state or frequent occurrence of extreme NAO maxima during the MCA (Abrantes et al., 2005), which agrees with the NAO reconstruction of Ortega et al. (2015). Furthermore, forest expansion indicates relatively warm conditions in both the northwestern and southern Iberian Peninsula (Fig. 4b), and these are in good agreement with atmospheric temperatures over NE Spain (Fig. 4e) (Martín-Chivelet et al., 2011), suggesting similar on-land conditions across northern Iberia.

However, our records show distinct conditions for the early MCA (900-1100 CE) where warm winters, cooler spring-fall and extreme precipitation characterize the northern Iberian Peninsula (Fig. 5). Increased fluvial input during the MCA, particularly intense around $1000 \mathrm{CE}$ is also observed at other sites in northern Iberia; Ria de Vigo (Álvarez et al., 2005) and Ria de Muros (Lebreiro et al., 2006). By contrast, the late MCA (1200-1300 CE) shows relatively cooler and stormy winters and warmer spring-fall (Fig. 5).

At present, precipitation occurs mainly as a result of the moisture carried by westerly winds that become predominant during NAO-negative phases (Trigo et al., 2004). However, Yang and Myers (2007) have proposed that persistent positive NAO conditions have also generated strong heat and moisture transport from the Atlantic.

A clear relationship between the NAO-derived atmospheric circulation over Europe and the decadal variability in north Atlantic surface temperatures (AMO), with northerly winds over Europe associated with a positive state of the AMO and zonal winds with its negative state has been shown by Yamamoto and Palter (2016). However, the clear imprint of AMO variability on European summer temperatures is not observed during wintertime. This is an absence attributed to a cancelation of the ocean SST expression by strong cold winds (Yamamoto and Palter, 2016).

Previous work from the Iberian/Atlantic ocean region (Abrantes et al., 2011) suggests coherence between SST at Porto and the AMO reconstructed instrumentally and by tree rings, implying a connection between the Iberian Peninsula coastal circulation and multidecadal variability in North Atlantic Ocean SSTs (Gra et al., 2004; Mann et al., 2010).

Frankcombe et al. (2010) propose that the AMO is dominated by two main timescales: 20-30 years associated with the AMOC (Atlantic Meridional Overturning Circulation), and so of ocean-internal origin, and 50-70 years related to the atmospheric exchange between the Atlantic and the Arctic Ocean. More recently, Buckley and Marshall (2016) revised the periodicities shown by various instrumental and proxy records and grouped them into decadal (20 years) and multidecadal ( $\pm 40-70$ years) and showed a statistical significance for the 70-year periodicity, supporting the notion that ocean dynamics play a significant role in the variability in European climate on multi-decadal timescales (Yamamoto and Palter, 2016; Zhang, 2007). 


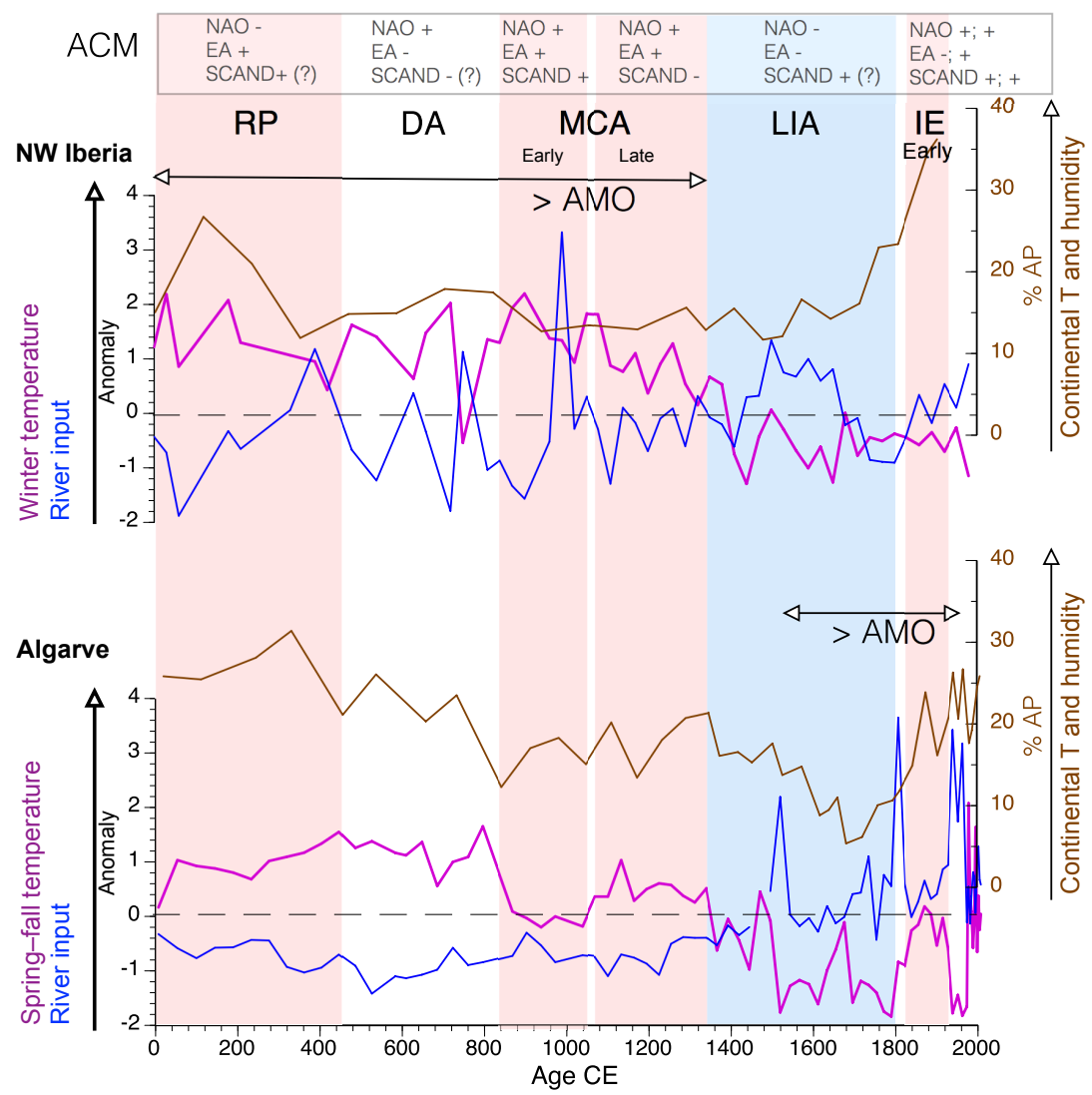

Figure 5. SST and river-input ([ $n$-alk] stacks for NW Iberia (Galiza, Minho and Porto) and continental $T$ and humidity conditions extracted from arboreal pollen (\% AP) at Minho are compared to the Algarve SST and [ $n$-alk] anomalies (for easier comparison) and \% AP. Pink bars mark the warmer periods (RP; MCA; Industrial Era - IE), and the blue bar marks the cold LIA. Periods of increased AMO that impact on either IP region are marked by AMO. The dominant state of the ACMs in the North Atlantic for the major climatic periods of the last 2000 years is depicted at the top of the figure (NAO; EA; SCAND). The consecutive negative and/or positive signs given for IE in the top bar (ACM) correspond to the early IE, 1850-1970, and the late IE, after 1970 CE.

To investigate the influence of the AMO on the weather regime over the Atlantic Iberian Peninsula, we performed wavelet analysis on our SST and [n-alk] records (Figs. 6, 7). Results reveal a 74-year periodicity for SST and precipitation on the west coast mainly before $1300 \mathrm{CE}$ and on the south coast after $1580 \mathrm{CE}$. In addition, longer-period processes (100-180 years) are found throughout the three SST records and before $1200 \mathrm{CE}$ in the precipitation stack (256 years). If our wavelet results are interpreted in the light of the abovepresented information, multi-decadal variability in the North Atlantic dynamics associated with the Atlantic and Arctic Ocean exchange have an important impact on SST and precipitation over the Atlantic sector of the Iberian Peninsula, mainly between 900 and $1200 \mathrm{CE}$ in the north and after $1580 \mathrm{CE}$ in the Algarve.

However, to explain the occurrence of big storms clustered in the early MCA on the northwestern Iberian Peninsula, the modern path of westerly winds under NAO-positive conditions would have to be positioned southward of $41^{\circ} \mathrm{N}$, a shift that could have been caused by an increase in midlatitude blocking anticyclones.

We must consider that (1) SCAND is related to major blocking anticyclones over Scandinavia and has a positive mode associated with above-average precipitation across southern Europe (Comas-Bru and McDermott, 2014; Jerez and Trigo, 2013), (2) the negative relation observed between NAO and precipitation in winter and the EA and SCAND positive relation to winter precipitation in the northern Iberian Peninsula, and (3) the slight positive relation of SCAND with precipitation in the north but with an important negative effect on temperature in the southern Iberian Peninsula in summer (Hernández et al., 2015). One possible explanation for the observed strong precipitation in the north and lower SST in the Algarve during the early MCA may be the effect of a positive SCAND (Fig. 5).

In summary, the interplay between North Atlantic multidecadal variability associated with the Atlantic and Arctic Ocean exchange and the positive modes of the NAO, EA and SCAND are inferred to explain extreme precipitation associ- 

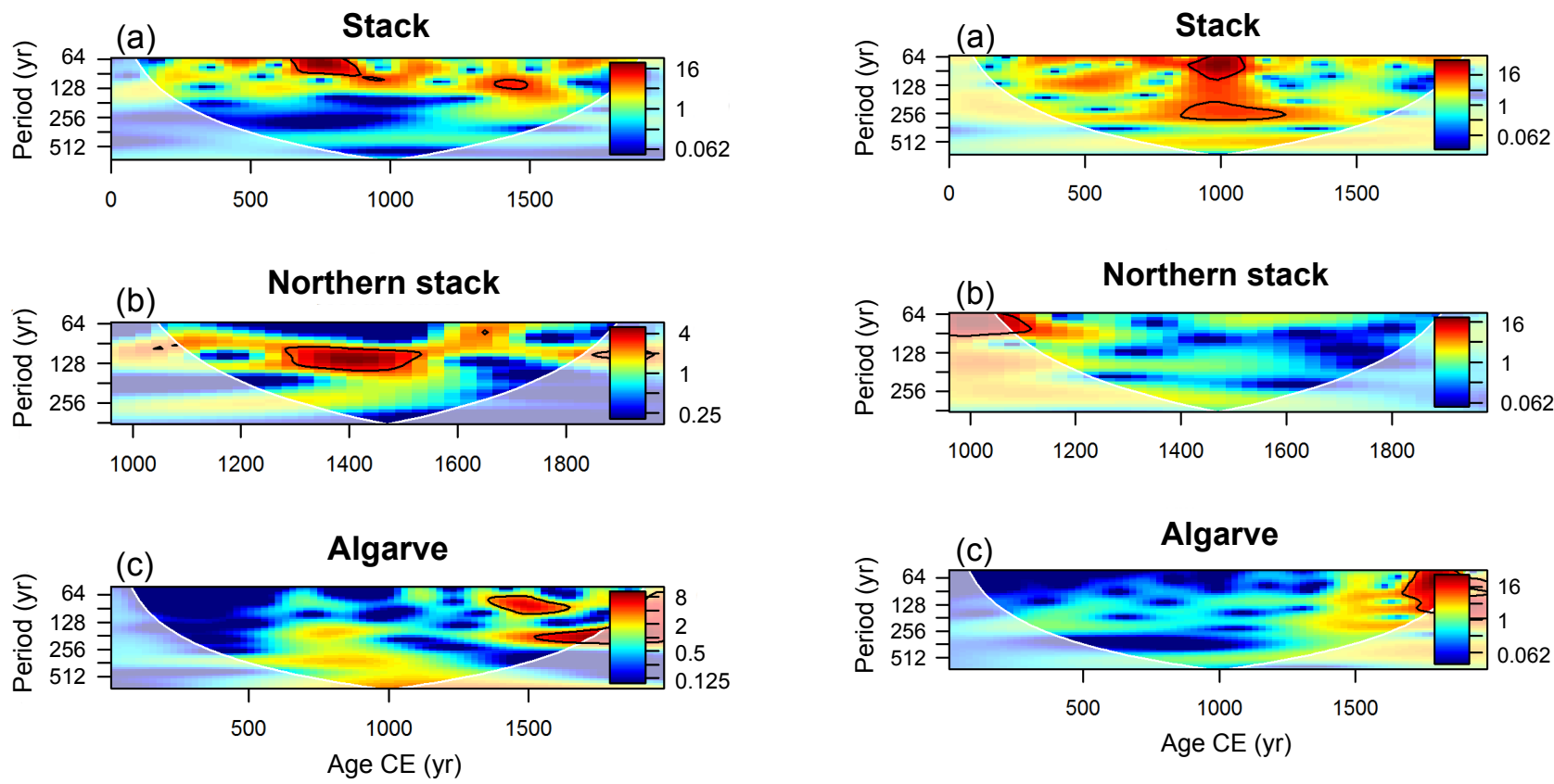

Figure 6. The continuous wavelet power spectrum of the SST stack (a); the north SST stack (b); and the Algarve SST record (c). The thick black contour designates the $95 \%$ confidence level, and the lighter shaded area represents the cone of influence (COI) where edge effects might distort the results.

ated with warm winters and cool summers observed in the Iberian Peninsula during the early MCA. By contrast, the cold stormy winters and warm summers of the late MCA are attributed to a shift in the SCAND to a negative mode.

\subsubsection{The warming of the Industrial Era: atmospheric forcing and oceanographic circulation changes}

The transition to the Industrial Era starts at 1750-1850 CE with an increase in SSTs to values similar to those detected prior to $1300 \mathrm{CE}$ in all but the Porto record (Figs. 2a, 5) (Abrantes et al., 2011). The same warming is detectable in all the AP pollen records (Fig. 4b), a pattern that coincides with the atmospheric temperature rise detected in NE Spain, Europe and the Northern Hemisphere (Luterbacher et al., 2016; Martín-Chivelet et al., 2011; Moberg et al., 2005) (Fig. 2d, e, f).

In contrast the SST stack anomaly curve shows a smooth signal when compared to the SST data during the same time frame (Fig. 2a, b). Indeed, the Porto and Algarve records show opposite SST patterns that cancel out and result in a leveled SST in the stack (Figs. 2a, 2b, 5). Superimposed on the 20th-century trend are decadal-scale oscillations of unusually large amplitude, but an inverse signal is detected for SST and river input in the Algarve (Figs. 2a, 5). Of particular note is the second rise of SST by the mid-20th century ( \pm 1970$)$ (Fig. 2a), which coincides with the highest global

temperatures of the last 1400 years (Ahmed et al., 2013) and agrees with a second warming phase in the western Mediterranean (Lionello et al., 2006).

Zampieri et al. (2016) proposed that the rapid warming periods of the Northern Hemisphere, including the last one in the 1990s, are mainly modulated by shifts in the AMO from negative (cold) to positive (warm) phases. A close look at the AMO index records of Gray et al. (2004) and Mann et al. (2010) (Fig. 2h) reveals that both warming steps (1850 and 1970 CE) do indeed occur during warming transitions in the AMO index, supporting the notion of a stronger influence of the North Atlantic SST pattern on southern Iberian climate as found for the central-western Mediterranean Sea (Cisneros et al., 2016).

In the Algarve, the highest SSTs are likely to reflect the warm inner-shelf counter current associated with largescale northerly winds during the upwelling season (Garel et al., 2016), which in turn are known to have registered a substantial intensification during the peak summer months (July to September) in the last 50 years in SW Iberia (Relvas et al., 2009). Furthermore, the occurrence of periods of strong precipitation when SST is low appears to be related to the change from a negative mode of the EA between 1900 and 1970 to a positive EA after 1970, while NAO and SCAND remain positive (Fig. 5; NOAA historical archive and indices - http://www.cpc.ncep.noaa.gov/data/teledoc/ 
telecontents.shtml; and http://www.cpc.ncep.noaa.gov/data/ teledoc/telecontents.shtml)

In summary, the mid-20th-century rise in SST in the Algarve emerges as a regional response to the unequivocal warming of the global ocean since the 1960s (IPCC, 2013b). The reverse trend registered at the Porto site compared to the southern records clearly demonstrates the regional differences that are likely to result from global warming via the complexities of the regional ocean dynamics (Seidov et al., 2017).

Considering the high relevance of such environmental changes to ecosystem organization and sustainability, a more in-depth discussion of its effect on the regional scale is necessary.

\section{Conclusions}

The combination of SST and terrestrial input or river discharge records from five sites distributed along the Iberian Margin ( 36 to $42^{\circ} \mathrm{N}$ ) captures the spatial distribution of temperature as well as continental precipitation for the last 2000 years on different timescales. Furthermore, the new regional stacks for SST and [ $n$-alk] provide a meaningful form to understand the role of global and hemispheric vs. regional variability.

Orbital-scale summer insolation imposes long-term cooling from $0 \mathrm{CE}$ to the beginning of the 20th century, at all latitudes with maximum amplitude at the southern sites. Century and decadal-scale climate changes follow the overall climatic patterns of the extratropical Northern Hemisphere and Europe. The RP and the DA climate records are explained by the mechanisms proposed by Sánchez-Lopez et al. (2015). The MCA shows two climate phases: the early MCA (900$1100 \mathrm{CE}$ ) with warm winters, cool summers and extreme flooding implies a link between AMO and a high-pressure blocking system over northwestern Europe (positive-like mode of the SCAND) as well as NAO and EA on a positive phase; the late MCA (1200-1300 CE) cold stormy winters and warm summers suggest a shift in SCAND to a negative mode

The LIA is marked by the coldest SSTs and frequent but not extreme storms attributed to a dominant negative NAO and EA modes. The Industrial Era starts by $1800 \mathrm{CE}$ and is marked with an SST rise in consonance with increasing influence from the internal North Atlantic ocean variability on the Atlantic Iberian Peninsula climate. A second increase in SST at \pm 1970 CE is particularly marked at the Algarve site as a regional imprint of the global warming impact previously simulated for southern Iberia.

Data availability. Primary data for the new sedimentary sequences are archived in PANGEA (https://doi.org/10.1594/PANGAEA.882269).

\section{The Supplement related to this article is available online at https://doi.org/10.5194/cp-13-1901-2017-supplement.}

Author contributions. FA: PI of the various projects that funded all the data combined in this paper; she had the idea and wrote the paper. TR: responsible for the biomarker analysis in all cores. MR: statistical data analysis. FN: responsible for the pollen interpretation and age models of DIVA and POPEI. ES: data from GeoB11033-1 core. DO: pollen analysis of the DIVA core. SD: pollen analysis for the Tagus site D13882 and POPEI core. AC: age model for core GeoB11033-1. PO processed the satellite-derived and OISST data. TD provided the Algarve core (POPEI). MMH participated in the DIVA cruise.

Competing interests. The authors declare that they have no conflict of interest.

Acknowledgements. The authors express their gratitude to the captain, crew and participants of the cruises Discovery 249, Poseidon PALEO I, RV Poseidon 342 - Galiomar and B/O Mytilus DIVA09 for their contribution during the retrieval of the various cores used in this study. Thanks are due in particular to Guilhermo F. Pedraz and the Departamento de Geociencias Marinas y Ordenación del Territorio (Universidade de Vigo) for allowing the recovery of the DIVA core on their DIVA09 cruise. Special acknowledgments are due to the anonymous referees of previous versions of this paper, who greatly contributed to its improvement.

Funding was provided by the projects INGMAR (FCT ARIPIPI Program - Support for State Labs Development), HOLSMEER (EVK2-CT-2000-00060), CLIMHOL (PTDC/AAC-CLI/100157/2008), MIÑO-MINHO (0234_NATURA_MM_1_E), POPEI (PDCT/MAR/55618/2004), CALIBERIA (PTDC/MAR/102045/2008, national funds from FCT - Foundation for Science and Technology and COMPETE/FEDERFCOMP-01-0124-FEDER-010599), CIIMAR (20132017 CIMAR) and CCMAR (Associated Lab PEstC/MAR/LA0015/2013 and UID/Multi/04326/2013). Funding also came from fellowships to Filipa Naughton (SFRH/BPD/36615/2007), Teresa Rodrigues (SFRH/BPD/66025/2009) and Emília Salgueiro (Ref. SFRH/BPD/26525/2006 \& SFRH/BPD/111433/2015). Marta Rufino was funded by contrato ciência 2007 and by a post-doctoral grant of the IPMA, within the EU project SAFI (FP7SPACE-2013-1, grant agreement no. 607155). Finally, we thank Apolonia Inês, Daniel Ferreira, Cremilde Monteiro for their help and support with the laboratory analysis and Zuzanna Stroynowski for revision of the English.

Edited by: David Thornalley

Reviewed by: two anonymous referees

\section{References}

Abrantes, F., Lebreiro, S., Rodrigues, T., Gil, I., BartelsJónsdóttir, H., Oliveira, P., Kissel, C., and Grimalt, J. 
O.: Shallow-marine sediment cores record climate variability and earthquake activity off Lisbon (Portugal) for the last 2000 years, Quaternary Sci. Rev., 24, 2477-2494, https://doi.org/10.1016/j.quascirev.2004.04.009, 2005. 2005.

Abrantes, F., Rodrigues, T., Montanari, B., Santos, C., Witt, L., Lopes, C., and Voelker, A. H. L.: Climate of the last millennium at the southern pole of the North Atlantic Oscillation: an innershelf sediment record of flooding and upwelling, Clim. Res., 48, 261-280, 2011

Ahmed, M., Anchukaitis, K. J., Asrat, A., Borgaonkar, H. P., Braida, M., Buckley, B. M., Buntgen, U., Chase, B. M., Christie, D. A., Cook, E. R., Curran, M. A. J., Diaz, H. F., Esper, J., Fan, Z.-X., Gaire, N. P., Ge, Q., Gergis, J., Gonzalez-Rouco, J. F., Goosse, H., Grab, S. W., Graham, N., Graham, R., Grosjean, M., Hanhijarvi, S. T., Kaufman, D. S., Kiefer, T., Kimura, K., Korhola, A. A., Krusic, P. J., Lara, A., Lezine, A.-M., Ljungqvist, F. C., Lorrey, A. M., Luterbacher, J., Masson-Delmotte, V., McCarroll, D., McConnell, J. R., McKay, N. P., Morales, M. S., Moy, A. D., Mulvaney, R., Mundo, I. A., Nakatsuka, T., Nash, D. J., Neukom, R., Nicholson, S. E., Oerter, H., Palmer, J. G., Phipps, S. J., Prieto, M. R., Rivera, A., Sano, M., Severi, M., Shanahan, T. M., Shao, X., Shi, F., Sigl, M., Smerdon, J. E., Solomina, O. N., Steig, E. J., Stenni, B., Thamban, M., Trouet, V., Turney, C. S. M., Umer, M., van Ommen, T., Verschuren, D., Viau, A. E., Villalba, R., Vinther, B. M., von Gunten, L., Wagner, S., Wahl, E. R., Wanner, H., Werner, J. P., White, J. W. C., Yasue, K., and Zorita, E.: Continental-scale temperature variability during the past two millennia, Nat. Geosci., 6, 339-346, https://doi.org/10.1038/ngeo1797, 2013.

Akima, H. and Gebhardt, A.: akima: Interpolation of Irregularly and Regularly Spaced Data, R package version 0.6-2, 2016.

Álvarez, M. C., Flores, J. A., Sierro, F. J., Diz, P., Francés, G., Pelejero, C., and Grimalt, J.: Millennial Surface water dynamics in the Ria de Vigo during the last 3000 years as revealed by coccoliths and molecular biomarkers, Paleogeogr. Paleocl., 218, 1-13, 2005

Bard, E., Raisbeck, G., Yiou, F., and Jouzel, J.: Comment on "Solar activity during the last 1000 years inferred from radionuclide records" by Muscheler et al. (2007), Quaternary Sci. Rev., 26, 2301-2308, 2007.

Barriendos, M.: Los riesgos climáticos a través de la historia: avances en el estudio de episodios atmosféricos extraordinarios, in: Riesgos naturales, edited by: Ayala-Carcedo, F. J. and Olcina, J., Ariel, Barcelona, 2002.

Barriendos, M. and Martin-Vide, J.: Secular climatic oscillations as indicated by catastrophic floods in the Spanish Mediterranean coastland area, Climate Change, 38, 473-491, 1998.

Barriendos, M. and Rodrigo, F. S.: Study of historical flood events on Spanish rivers using documentary data, Hydrolog. Sci. J., 51, 765-783, 2006.

Benito, G. and Hudson, P.: Flood hazards: The context of fluvial Geomorphology, in: Geomorphological Hazards and Disaster Prevention, edited by: Alcántara-Ayala, I. and Goudie, A., Cambridge University Press 2010.

Benito, G., Sopeña, A., Sánchez-Moya, Y., Machado, M. A. J., and Pérez-González, A.: Palaeoflood record of the Tagus River (Central Spain) during the Late Pleistocene and Holocene, Quaternary Sci. Rev., 22, 1737-1756, 2003.
Benito, G., Díez-Herrero, A., and Fernández de Villalta, M.: Flood Response to Solar Activity in the Tagus Basin (Central Spain) over the Last Millennium, Climatic Change, 66, 27-28, 2004.

Benito, G., Barriendos, M., Llasat, M. C., Machado, M. J., and Thorndycraft, V. R.: Impacts on natural hazards of climatic origin, A. Flood risk, in: Preliminary Evaluation of the Impacts of Climate Change in Spain, edited by: Moreno, J. M., Ministerio de Medio Ambiente, Madrid, 2005.

Bradley, R. S. and Jones, P. D.: Little Ice Age' summer temperature variations: their nature and relevance to recent global warming trends, Holocene, 3, 367-376, 1993.

Buckley, M. W. and Marshall, J.: Observations, inferences, and mechanisms of the Atlantic Meridional Overturning Circulation: A review, Rev. Geophys., 54, 5-63, 2016.

Büntgen, U., Tegel, W., Nicolussi, K., McCormick, M., Frank, D., Trouet, V., Kaplan, J. O., Herzig, F., Heussner, K.-U., Wanner, H., Luterbacher, J., and Esper, J.: 2500 Years of European Climate Variability and Human Susceptibility, Science, 331, 578$582,2011$.

Cabrita, A. N.: A Cheia Grande no Guadiana, 7 de Dezembro de 1876, in: Eventos Meteorológicos, Estremoz, 2007.

Calvert, S. E. and Pedersen, T. F.: Chapter Fourteen Elemental Proxies for Palaeoclimatic and Palaeoceanographic Variability in Marine Sediments: Interpretation and Application, in: Developments in Marine Geology, edited by: Claude, H. M. and Anne De, V., Elsevier, 2007.

Cardeira, S., Rita, F., Relvas, P., and Cravo, A.: Chlorophyll a and chemical signatures during an upwelling event off the South Portuguese coast (SW Iberia), Cont. Shelf Res., 52, 133-149, 2013.

Cisneros, M., Cacho, I., Frigola, J., Canals, M., Masqué, P., Martrat, B., Casado, M., Grimalt, J. O., Pena, L. D., Margaritelli, G., and Lirer, F.: Sea surface temperature variability in the central-western Mediterranean Sea during the last 2700 years: a multi-proxy and multi-record approach, Clim. Past, 12, 849-869, https://doi.org/10.5194/cp-12-849-2016, 2016.

Climate, E.: ESPON CLIMATE - Climate Change and Territorial Effects on Regions and Local Economies in Europe, Applied Research 2013/1/4, Draft Final Report Version 25/2/2011, TU Dortmund University, Germany, 2011

Comas-Bru, L. and McDermott, F.: Impacts of the EA and SCA patterns on the European twentieth century NAO - winter climate relationship, Q. J. Roy. Meteor. Soc., 140, 354-363, 2014.

Cook, E., D'Arrigo R. D., and ME, M.: A well-verified, multiproxy reconstruction of the winter North Atlantic Oscillation index since A.D. 400, J. Clim., 15, 1754-1764, 2002.

Cook, E. R., Esper, J., and D’Arrigo, R. D.: Extra-tropical Northern Hemisphere land temperature variability over the past 1000 years, Quaternary Sci. Rev., 23, 2063-2074, 2004.

Crowley, J. and Unterman, M. B.: Technical details concerning development of a 1200-yr proxy index for global volcanism, Crowley AOD-Reff, Earth Syst. Sci. Data, 5, 187-197, https://doi.org/10.5194/essd-5-187-2013, 2013.

Cunningham, L. K., Austin, W. E. N., Knudsen, K. L., Eiríksson, J., Scourse, J. D., Wanamaker, A. D., Butler, P. G., Cage, A. G., Richter, T., Husum, K., Hald, M., Andersson, C., Zorita, E., Linderholm, H. W., Gunnarson, B. E., Sicre, M.-A., Sejrup, H. P., Jiang, H., and Wilson, R. J. S.: Reconstructions of surface ocean conditions from the northeast Atlantic and Nordic seas during the last millennium, Holocene, 23, 921-935, 2013. 
Desprat, S., Sánchez Goñi, M. A. F., and Loutre, M.-F.: Revealing climatic variability of the last three millennia in northwestern Iberia using pollen influx data, Earth Planet. Sc. Lett., 213, 63-78, 2003.

Diz, P., Francés, G., Pelejero, C., Grimalt, J. O., and Vilas, F.: The last 3000 years in the Ría de Vigo (NW Iberian Margin): climatic and hydrographic signals, Holocene, 12, 459-468, 2002.

Eglinton, G. and Hamilton, R. J.: Leaf epicuticular waxes, Science, 156, 1322-1335, 1967.

Eglinton, G., Bradshaw, S. A., Rosell, A., Sarnthein, M., Pflaumann, U., and Tiedemann, R.: Molecular record of secular sea surface temperature changes on 100-year timescales for glacial terminations I, II and IV, Nature, 356, 423-426, 1992.

Esper, J., Cook, E. R., and Schweingruber, F. H.: Low-Frequency Signals in Long Tre-Ring Chronologies for Reconstructing Past Temperature, Science, 295, 2250-2253, 2002.

Fernández-Donado, L., González-Rouco, J. F., Raible, C. C., Ammann, C. M., Barriopedro, D., García-Bustamante, E., Jungclaus, J. H., Lorenz, S. J., Luterbacher, J., Phipps, S. J., Servonnat, J., Swingedouw, D., Tett, S. F. B., Wagner, S., Yiou, P., and Zorita, E.: Large-scale temperature response to external forcing in simulations and reconstructions of the last millennium, Clim. Past, 9, 393-421, https://doi.org/10.5194/cp-9-393-2013, 2013.

Fiúza, A.: The Portuguese Coastal Upwelling, Lisbon, 45-71, 1982.

Fiúza, A.: Upwelling patterns off Portugal, in: Coastal Upwelling its sediment record, edited by: Suess, E. and Thiede, J., Plenum, New York, 1983.

Fiúza, A. and Macedo, M. E.: Climatological space and time variation of the Portuguese coastal upwelling, Oceanol. Acta, 5, 3140, 1982.

Fiúza, A. A. and Frouin, T. B. R.: Observations of a Warm Oceanic Current Flowing Northward along the Coasts Of Potugal and Spain During November-December 1983, Eos Trans. AGU, 67, 867-1302, https://doi.org/10.1029/EO067i044p00867, 1986.

Frankcombe, L. M., von der Heydt, A., and Dijkstra, H. A.: North Atlantic Multidecadal Climate Variability: An Investigation of Dominant Time Scales and Processes, J. Clim., 23, 3616-3638, 2010.

Garel, E., Laiz, I., Drago, T., and Relvas, P.: Characterisation of coastal counter-currents on the inner shelf of the Gulf of Cadiz, J. Marine Syst., 155, 19-34, 2016.

Giorgi, F.: Climate change hot-spots, Geophys. Res. Lett., 33, L08707, https://doi.org/10.1029/2006GL025734, 2006.

Gouhier, T. C., Grinstead, A., and Simko, V.: biwavelet: Conduct univariate and bivariate wavelet analyses (Version 0.20.10), 2016.

Gray, S. T., Graumlich, L. J., Betancourt, J. L., and Pederson, G. T.: A tree-ring based reconstruction of the Atlantic Multidecadal Oscillation since 1567 A.D., Geophys. Res. Lett., 31, L12205, https://doi.org/10.11029/12004GL019932, 2004.

Guiot, J. and Cramer, W.: Climate change: The 2015 Paris Agreement thresholds and Mediterranean basin ecosystems, Science, 354, 465-468, 2016.

Hegerl, G. C., Crowley, T. J., Hyde, W. T., and Frame, D. J.: Climate sensitivity constrained by temperature reconstructions over the past seven centuries, Nature, 440, 1029-1032, 2006.

Hernández, A., Trigo, R. M., Pla-Rabes, S., Valero-Garcés, B. L., Jerez, S., Rico-Herrero, M., Vega, J. C., Jambrina-Enríquez, M., and Giralt, S.: Sensitivity of two Iberian lakes to North Atlantic atmospheric circulation modes, Clim. Dynam., 45, 3403-3417, 2015.

Hurrell, J.: Decadal trends in the North Atlantic Oscillation - regional temperatures and precipitation, Science, 269, 676-679, 1995.

Iglesias, I., Avilez-Valente, P., Couvelard, X., and Caldeira, R.: Geostrophic influence in the River Douro plume: a climatological study, V Conferência Nacional de Mecânica dos Fluidos, Termodinâmica e Energia MEFTE 2014, 11-12 Setembro 2014, Porto, Portugal APMTAC, 2014.

IPCC: Annex II: Climate System Scenario Tables In: Climate Change 2013: The Physical Science Basis, Contribution of Working Group I to the Fifth Assessment Report of the Intergovernmental Panel on Climate Change, edited by: Stocker, T. F., Qin, D., Plattner, G.-K., Tignor, M., Allen, S. K., Boschung, J., Nauels, A., Xia, Y., Bex, V., and Midgley, P. M., Cambridge University Press, Cambridge, United Kingdom and New York, NY, USA, 2013a.

IPCC: Climate Change 2013: The Physical Science Basis. Contribution of Working Group I to the Fifth Assessment Report of the Intergovernmental Panel on Climate Change, Cambridge University Press, Cambridge, United Kingdom and New York, NY, USA, 2013b.

Jambrina-Enríquez, M., Sachse, D., and Valero-Garcés, B. L.: A deglaciation and Holocene biomarker-based reconstruction of climate and environmental variability in NW Iberian Peninsula: the Sanabria Lake sequence, J. Paleolimnol., 56, 49-66, 2016.

Jerez, S. and Trigo, R. M.: Time-scale and extent at which largescale circulation modes determine the wind and solar potential in the Iberian Peninsula, Enviro. Res. Lett., 8, 044035, https://doi.org/10.1088/1748-9326/8/4/044035, 2013.

Jones, P. D., Osborn, T. J., and Briffa, K. R.: The Evolution of Climate Over the Last Millenium, Science, 292, 662-667, 2001.

Lebreiro, S. M., Francés, G., Abrantes, F. F. G., Diz, P., BartelsJónsdóttir, H. B., Stroynowski, Z. N., Gil, I. M., Pena, L. D., Rodrigues, T., Jones, P. D., Nombela, M. A., Alejo, I., Briffa, K. R., Harris, I., and Grimalt, J. O.: Climate change and coastal hydrographic response along the Atlantic Iberian margin (Tagus Prodelta and Muros Ría) during the last two millennia, Holocene, 16, 1003-1015, 2006.

Lionello, P., Malanott-Rizzoli, R., Boscolo, R., Alpert, P., Artale, V., Li, L., Luterbacher, J., May, W., Trigo, R., Tsimplis, M., Ulbrich, U., and Xoplaki, E. T.: The Mediterranean climate: An overview of the main characteristics and issues, in: Mediterranean Climate Variability (MedClivar), Elsevier, Amsterdam, 2006.

Lisiecki, L. E. and Raymo, M. E.: A Pliocene-Pleistocene stack of 57 globally distributed benthic $\delta^{18} \mathrm{O}$ records, Paleoceanography, 20, https://doi.org/10.1029/2004PA001071, 2005.

Luterbacher, J., Xoplaki, E., Dietrich, D., Jones, P. D., Davies, T. D., Portis, D., Gonzalez-Rouco, J. F., von Storch, H., Gyalistras, D., Casty, C., and Wanner, H.: Extending North Atlantic Oscillation Reconstructions Back to 1500, Atmos. Sci. Lett., 2, 114-124, 2002.

Luterbacher, J., Dietrich, D., Xoplaki, E., Grosjean, M., and Wanner, H.: European Seasonal and Annual Temperature Variability, Trends, and Extremes Since 1500, Science, 303, 1499-1503, https://doi.org/10.1126/science.1093877, 2004.

Luterbacher, J., Werner, J. P., Smerdon, J. E., Fernández-Donado, L., González-Rouco, F. J., Barriopedro, D., Ljungqvist, F. C., 
Büntgen, U., Zorita, E., Wagner, S., Esper, J., McCarroll, D., Toreti, A., Frank, D., Jungclaus, J. H., Barriendos, M., Bertolin, C., Bothe, O., Brázdil, R., Camuffo, D., Dobrovolný, P., Gagen, M., García-Bustamante, E., Ge, Q., Gómez-Navarro, J. J., Guiot, J., Hao, Z., Hegerl, G. C., Holmgren, K., Klimenko, V. V., Martín-Chivelet, J., Pfister, C., Roberts, N., Schindler, A., Schurer, A., Solomina, O., von Gunten, L., Wahl, E., Wanner, H., Wetter, O., Xoplaki, E., Yuan, N., Zanchettin, D., Zhang, H., and Zerefos, C.: European summer temperatures since Roman times, Environ. Res. Lett., 11, 024001, https://doi.org/10.1088/17489326/11/2/024001, 2016.

Mann, M. E., Zhang, Z., Rutherford, S., Bradley, R. S., Hughes, M. K., Shindell, D., Ammann, C., Faluvegi, G., and Ni., F.: Global Signatures and Dynamical Origins of the Little Ice Age and Medieval Climate Anomaly, Science, 326, 1256-1260, 2010.

Marta-Almeida, M., Dubert, J., and Peliz, Á.: Simulations of extreme shelf current along the North-Western Iberian Shelf forced by wind and river runoff, Valencia, Spain, 1555-1559, 2002.

Martín-Chivelet, J., Muñoz-García, M. B., Edwards, R. L., Turrero, M. J., and Ortega, A. I.: Land surface temperature changes in Northern Iberia since 4000 years BP, based on $\delta^{13} \mathrm{C}$ of speleothems, Glob. Planet. Change, 77, 1-12, 2011.

McGregor, H. V., Evans, M. N., Goosse, H., Leduc, G., Martrat, B., Addison, J. A., Mortyn, P. G., Oppo, D. W., Seidenkrantz, M.-S., Sicre, M.-A., Phipps, S. J., Selvaraj, K., Thirumalai, K., Filipsson, H. L., and Ersek, V.: Robust global ocean cooling trend for the pre-industrial Common Era, Nat. Geosci., 8, 671-677, 2015.

McKim, D. K.: Common Era entry, Westminster John Knox Press, Louisville, Kentucky, 1998.

Mendes, R., Sousa, M. C., deCastro, M., Gómez-Gesteira, M., and Dias, J. M.: New insights into the Western Iberian Buoyant Plume: Interaction between the Douro and Minho River plumes under winter conditions, Prog. Oceanogr., 141, 30-43, 2016.

Miranda, P., M. A., Coelho, F. E. S., Tomé, A. R., Valente, M. A., Carvalho, A., Pires, C., Pires, H. O., Pires, V. C., and Ramalho, C.: 20th Century Portuguese Climate and Climate Scenarios, in: Climate Changes in Portugal: Scenarios, Impacts and Adaptation Measures (SIAM Project), edited by: Santos, F. D., Forbes, K., and Moita, R., Gradiva, 2002.

Moberg, A., Sonechkin, D. M., Holmgren, K., Datsenko, N. M., and Karlén, W. H.: Highly variable Northern Hemisphere temperatures reconstructed from low- and high-resolution data, Nature, 433, 613-617, 2005.

Moore, P. D., Webb, J. A., and Collinson, M. E.: Pollen analysis, Blackwell scientific publication, Oxford, 216 pp., 1991.

Morellón, M., Valero-GarcÉS, B., Anselmetti, F., Ariztegui, D., Schnellmann, M., Moreno, A. N. A., Mata, P., Rico, M., and Corella, J. P.: Late Quaternary deposition and facies model for karstic Lake Estanya (North-eastern Spain), Sedimentology, 56, 1505-1534, 2009.

Moreno, A., Valero-Garcés, B. L., González-Sampériz, P., and Rico, M.: Flood response to rainfall variability during the last 2000 years inferred from the Taravilla Lake record (Central Iberian Range, Spain), J. Paleolimnol., 40, 943-961, 2008.

Moreno, A., Morellón, M., Martín-Puertas, C., Frigola, J., Canals, M., Cacho, I., Corella, J. P., Pérez, A., Belmonte, Á., VegasVilarrúbia, T., González-Sampériz, P., and Valero-Garcés, B. L.: Was there a common hydrological pattern in the Iberian Penin- sula region during the Medieval Climate Anomaly?, PAGES news, 19, 16-18, 2011.

Muller, P. J., Kirst, G., Rohland, G., von Storch, I., and RosellMele, A.: Calibration of the alkenone paleotemperature index $\mathrm{U}_{37}^{K^{\prime}}$ based on core-tops from the eastern South Atlantic and the global ocean $\left(60^{\circ} \mathrm{N}-60^{\circ} \mathrm{S}\right)$, Geochim. Cosmochim. Ac., 62, 1757-1772, 1998.

Naughton, F., Sanchez Goñi, M. F., Desprat, S., Turon, J. L., Duprat, J., Malaizé, B., Joli, C., Cortijo, E., Drago, T., and Freitas, M. C.: Present-day and past (last 2000 years) marine pollen signal off western Iberia, Mar. Micropaleontol., 62, 91-114, 2007.

Oliveira, P. B., Moita, T., Catarino, R., and da Silva, A.: Wintertime SST and Chla off NW Iberian shelf from satellite and insitu data, Amsterdam, 24-28 September 2007.

Otero, P., Ruiz-Villarreal, M., and Peliz, A.: Variability of river plumes off Northwest Iberia in response to wind events, J. Marine Syst., 72, 238-255, 2008.

Peliz, Á., Rosa, T. L., Santos, A. P., and Pissarra, J. L.: Fronts, jets, and counter-flows in the Western Iberian upwelling system, J. Marine Syst., 35, 61-77, 2002.

Peliz, Á., Dubert, J., Santos, A. M. P., Oliveira, P. B., and Le Cann, B.: Winter upper ocean circulation in the Western Iberian Basin Fronts, Eddies and Poleward Flows: an overview, Deep-Sea Res. Pt. I, 52, 621-646, 2005.

Pena, L. D., Francés, G., Diz, P., Esparza, M., Grimalt, J. O., Nombela, M. A., and Alejo, I.: Climate fluctuations during the Holocene in NW Iberia: High and low latitude linkages, Cont. Shelf Res., 30, 1487-1496, 2010.

R Core Team: R: A Language and Environment for Statistical Computing, Vienna, Austria: the R Foundation for Statistical Computing, ISBN: 3-900051-07-0, available online at: http://www. R-project.org/, 2016.

Reille, M.: Pollen et spores d'Europe et d'Afrique du Nord, Laboratoire de botanique historique et palynologie, Marseille, 1992.

Reimer, P., Baillie, M., Bard, E., Bayliss, A., Beck, J., Bertrand, C., Blackwell, P., Buck, C., Burr, G., Cutler, K., Damon, P., Edwards, R., Fairbanks, R., Friedrich, M., Guilderson, T., Hughen, K., Kromer, B., McCormac, F., Manning, Ramsey, C. B., Reimer, R., Remmele, S., Southon, J., Stuiver, M., Talamo, S., Taylor, F., van der Plicht, J., and Weyhenmeyer, C.: Marine04 Marine radiocarbon age calibration, 26-0 ka BP, Radiocarbon, 46, 10291058, 2004.

Relvas, P., Barton, E., Dubert, J., Oliveira, P. B., Peliz, A., da Silva, J., and Santos, A. M. P.: Physical oceanography of the western Iberia ecosystem: Latest views and challenges, Prog. Oceanogr., 74, 149-173, 2007.

Relvas, P. and Barton, E. D.: Mesoscale patterns in the Cape São Vicente (Iberian Peninsula) upwelling region, J. Geophys. Res., 107, 21-23, 2002.

Relvas, P., Luis, J., and Santos, A. M. P.: Importance of the mesoscale in the decadal changes observed in the northern Canary upwelling system, Geophys. Res. Lett., 36, L22601, https://doi.org/10.1029/2009GL040504, 2009.

Rodrigues, T., Grimalt, J. O., Abrantes, F. G., Flores, J. A., and Lebreiro, S. M.: Holocene interdependences of changes in sea surface temperature, productivity, and fluvial inputs in the Iberian continental shelf (Tagus mud patch), Geochem. Geophy. Geosy. 10, Q07U06, https://doi.org/10.1029/2008GC002367, 2009. 
Romero-Viana, L., Julià, R., Schimmel, M., Camacho, A., Vicente, E., and Miracle, M. R.: Reconstruction of annual winter rainfall since A.D. 1579 in centraleastern Spain based on calcite laminated sediment from Lake La Cruz, Climate Change, 107, 343361, 2011.

Rosell-Melé, A., Carter, J. A., and Eglinton, G.: Survey of distribution of long-chain alkenones and alkyl alkenoates in marine surface sediments from the North East Atlantic, Org. Geochem., 22, 501-509, 1994.

Saenger, C., Came, R. E., Oppo, D. W., Keigwin, L. D., and Cohen, A. L.: Regional climate variability in the western subtropical North Atlantic during the past two millennia, Paleoceanography, 26, PA2206, https://doi.org/10.1029/2010PA002038, 2011.

Sánchez, R. F. and Relvas, P.: Spring-summer climatological circulation in the upper layer in the region of Cape St. Vincent, Southwest Portugal, ICES J. Mar. Sci., 60, 1232-1250, 2003.

Sánchez-López, G., Hernández, A., Pla-Rabes, S., Trigo, R. M., Toro, M., Granados, I., Sáez, A., Masqué, P., Pueyo, J. J., RubioInglés, M. J., and Giralt, S.: Climate reconstruction for the last two millennia in central Iberia: The role of East Atlantic (EA), North Atlantic Oscillation (NAO) and their interplay over the Iberian Peninsula, Quaternary Sci. Rev., 149, 135-150, 2016.

Schurer, A. P., Tett, S. F. B., and Hegerl, G. C.: Small influence of solar variability on climate over the past millennium, Nat. Geosci., 7, 104-108, 2014.

Seidov, D., Mishonov, A., Reagan, J., and Parsons, R.: Multidecadal variability and climate shift in the North Atlantic Ocean, Geophys. Res. Lett., 44, 4985-4993, 2017.

Solanki, S. K., Usoskin, I. G., Kromer, B., Schüssler, M., and Beer, J.: An unusually active Sun during recent decades compared to the previous 11,000 years, Nature, 431, 1084-1087, 2004.

Steinhilber, F., Abreu, J. A., Beer, J., Brunner, I., Christl, M., Fischer, H., Heikkilä, U., Kubik, P. W., Mann, M., McCracken, K. G., H. Miller, Miyahara, H., Oerter, H., and Wilhelms, F.: 9,400 years of cosmic radiation and solar activity from ice cores and tree rings, P. Natl. Acad. Sci. USA, https://doi.org/10.1073/pnas.1118965109, 2012.

Teles-Machado, A., Peliz, Á., McWilliams, J. C., Cardoso, R. M., Soares, P. M. M., and Miranda, P. M. A.: On the year-to-year changes of the Iberian Poleward Current, J. Geophys. Res.Ocean., 120, 4980-4999, 2015.

Torrence, C. and Compo, G. P.: A practical guide to wavelet analysis, B. Am. Meteorol. Soc., 79, 61-78, 1998.

Touchan, R., Xoplaki, E., Funkhouser, G., Luterbacher, J., Hughes, M. K., Erkan, N., Akkemik, Ü., and Stephan, J.: Reconstructions of Spring/Summer Precipitation for the Eastern Mediterranean from Tree-Ring Widths and its Connection to Large-Scale Atmospheric Circulation, Clim. Dynam., 25, 75-98, 2005.

Trigo, R. M., Pozo-Vázquez, D., Osborn, T. J., Castro-Díez, Y., Gámiz-Fortis, S., and Esteban-Parra, M. J.: North Atlantic oscillation influence on precipitation, river flow and water resources in the Iberian Peninsula, Int. J. Climatol., 24, 925-944, 2004.
Trouet, V., Esper, J., Graham, N. E., Baker, A., Scourse, J. D., and Frank, D. C.: Persistent Positive North Atlantic Oscillation Mode Dominated the Medieval Climate Anomaly, Science, 324, 78-80, 2009.

Tullot, I.: Historical documentation of Spain's climate, Madrid, 1988.

Turner, T. E., Swindles, G. T., Charman, D. J., Langdon, P. G., Morris, P. J., Booth, R. K., Parry, L. E., and Nichols, J. E.: Solar cycles or random processes? Evaluating solar variability in Holocene climate records, Sci. Rep., 6, 23961, https://doi.org/10.1038/srep23961, 2016.

Usoskin, I. G., Solanki, S. K., and Kovaltsov, G. A.: Grand minima of solar activity during the last millennia, Proceedings of the International Astronomical Union, 7, 372-382, 2011.

Valero-Garcés, B. L., González-Sampériz, P., Navas, A., Machín, J., Mata, P., Delgado-Huertas, A., Bao, R., Moreno, A., Carrión, J. S., Schwalb, A., and González-Barrios, A.: Human Impact Since Medieval Times and Recent Ecological Restorationin a Mediterranean Lake: The Laguna Zoñar, Southern Spain, J. Paleolimnol., 35, 441-465, 2006.

Varzeano, J.: Há um século a grande cheia do Guadiana provocou tragédia em Alcoutim. In: Jornal do Algarve, Vila Real de Santo António, 1976.

Villanueva, J.: Estudi de les variaciones climàtiques i oceanogràfiques a 1'atlantic Nord Durant els últims 300.000 anys mitjançant l'análisi de marcadores moleculars, 1996, Dep.Química Ambiental, Universitat de Barcelona, Barcelona, 186 pp., 1996.

Villanueva, J. and Grimalt, J. O.: Gas Chromatographic Tuning of the $U k^{\prime} 37$ Paleothermometer, Anal. Chem., 69, 3329-3332, 1997.

Villanueva, J., Pelejero, C., and Grimalt, J. O.: Clean-up procedures for the unbiased estimation of $\mathrm{C}_{37}$ alkenone sea surface temperatures and terrigenous n-alkane in paleoceanography, J. Chromatogr., A757, 145-151, 1997.

Yamamoto, A. and Palter, J. B.: The absence of an Atlantic imprint on the multidecadal variability of wintertime European temperature, Nat. Commun., 7, 10930, https://doi.org/10.1038/ncomms10930, 2016.

Zampieri, M., Toreti, A., Schindler, A., Scoccimarro, E., and Gualdi, S.: Atlantic multi-decadal oscillation influence on weather regimes over Europe and the Mediterranean in spring and summer, Glob. Planet. Change, https://doi.org/10.1016/j.gloplacha.2016.08.014, 2016.

Zhang, R.: Anticorrelated multidecadal variations between surface and subsurface tropical North Atlantic, Geophys. Res. Lett., 34, L12713, https://doi.org/10.1029/2007GL030225, 2007. 